\title{
TEKST PSALMU 151 W RĘKOPISIE 11Q5 Z QUMRAN I W SEPTUAGINCIE. PROBLEM USTALENIA PIERWOTNEJ REDAKCJI
}

\section{Historia badań nad kwestią, tekst psalmu}

Psalm 151 był znany od dawna w starożytnych przekładach Biblii, a mianowicie greckim, syryjskim, łacińskim i kilku późniejszych. ${ }^{1}$ W lutym 1956 r. w 11 grocie Qumran został odnaleziony zwój 11Q5 $\left(11 \mathrm{QPs}^{\mathrm{a}}\right)$, w którym, jak później się okazalo, zachowała się znaczna część hebrajskiej wersji psalmu. W rękopisie utwór jest podzielony na dwa psalmy, które oznaczono jako Ps 151A (tekst odpowiada greckiemu Ps 151,1-5) i Ps 151B (Ps 151,6-7). Niestety, tekst drugiego psalmu zachował się bardzo źle, dlatego artykuł ten będzie dotyczył Ps $151 \mathrm{~A} .^{2}$

Nie ulega wątpliwości, że tłumaczenia Septuaginty dokonano nie z tej redakcji tekstu, która zachowała się w 11Q5. ${ }^{3}$ Wynika z tego

1 Greckie tłumaczenie Septuaginty stało się źródłem dla wszystkich innych z prawdopodobnym wyjątkiem syryjskiego. W sprawie syryjskiego przekładu istnieją dwa przeciwstawne poglądy. J. M a g n e, Les textes grec et syriaque du Psaume 151, RevQ 8/1975, s. 548-564, uważa syryjski przekład za niezależny podczas gdy D. N. W i g t i l, The Sequence of the Translations of Apocryphal Psalm 151, RevQ 11/1982-1984, s. 401-407, mówi o tym, że ten przekład opiera się na tłumaczeniu Septuaginty. Także I. S̆. Šifman uważa, że syryjski tłumacz korzystał z tekstu greckiego, ale również miał przed oczami tekst hebrajski: И. Ш. Ш и ф м а н, Псалом 151 (Опыт текстологического исследования), Письменные памятники Востока: Историко-филологические исследования 1978-1979, Москва 1987, s. 146-155.

${ }^{2} \mathrm{O}$ wtórności tego podziału zob. R. S t i c h e l, Beiträge zur frühen Geschichte des Psalters und zur Wirkungsgeschichte der Psalmen, ANWAW 116, Paderborn 2007, s. 335.

3 J. A. S a n d e r s, The Psalms Scroll of Qumrân Cave $11\left(11 Q P s^{a}\right)$, DJD IV, Oxford 1965, s. 59; M. W o j c i e c h o w s k i, Apokryfy z Biblii greckiej, Warszawa 2001, s. 11; M. D e I c o r, Zum Psalter von Qumran, BZ 10/1966, s. 16; E. O ß w a I d, Der gegenwärtige Stand der Erforschung der in Palästina neu gefundenen hebräischen Handschriften: Die Psalmenrolle aus Höhle 11 (11QPs ${ }^{a}$, TL 91/1966, s. 732; B. S t o r f j e 11, Chiastic Structure of Psalm 151, AUSS 25/1987, s. 98; M. S. S m i t h, How to Write a Poem: The Case of Psalm 151A in IIQPS 28:3-12, w: T. M u r a o k a, J. F. E I w o I d e (red.), The Hebrew of the Dead Sea Scrolls and Ben Sira: Proceedings of a Symposium held at Leiden University, 11-14 December 1995. STDJ 26, Leiden, 1997, s. 185-186. R. Meyer zaś nazywa tekst I1Q5 „pośrednim“ (mittelbar) 
pytanie, który z tekstów należy uważać za pierwotny: psalm z 11Q5 czy przypuszczalne hebrajskie Vorlage Septuaginty. Grecki tekst jest znacznie krótszy niż tekst qumrańskiego psalmu. ${ }^{4}$ Najpełniejszy opis wariantów tekstowych w tych dwóch wersjach można znaleźć w pracach J. A. Sandersa, ${ }^{5}$ J. Strugnella, ${ }^{6}$ M. S. Smitha ${ }^{7}$ i D. Amary. ${ }^{8}$

Qumrański tekst Psalmu 151 został najpierw wydany oddzielnie, ${ }^{9}$ później zaś razem $\mathrm{z}$ całym rękopisem w ramach serii „Discoveries in the Judaean Desert (of Jordan)".10 Właśnie ta druga publikacja stała się punktem wyjściowym do dyskusji o pierwotności jednej z redakcji tekstu, ponieważ w niej J. A. Sanders stwierdził, że krótsza wersja psalmu jest wtórnym skrótem dłuższej, który to skrót jest gorszy nie tylko w planie estetyki, lecz także w planie treści. ${ }^{11}$ Ten punkt widzenia został szeroko przyjęty, ${ }^{12}$ mimo że prawie nikt nie wysuwał argumentów w jego obronie. ${ }^{13}$ Nieco później J. A. Sanders powie, że dłuższa wersja tekstu jest pierwotna według opinii powszechnej. ${ }^{14}$

Vorlage Septuaginty. Odnotowuje, że greckie tłumaczenie wzoruje się na wersji hebrajskiej, którą można nazwać zniekształceniem qumrańskiego tekstu o charakterze zupełnie mechanicznym: R. M e y e r, Septuaginta-Fassung von Psalm 151,1-5 als Ergebnis einer dogmatischen Korrektur, w: F. M a s s (red.), Das ferne und nahe Wort: Festschrift für Leonhard Rost zur Vollendung seines 70. Lebensjahres am 30. November 1966 gewidmet, BZAW 105, Berlin 1967, s. 164-170.

4 Sam Ps 151A jest większy niż cały tekst grecki.

5 J. A. S a n d e r s, The Psalms Scroll, s. 54-61.

6 J. S t r u g n e ll, Notes on the Text and Transmission of the Apocryphal Psalms 151, 154 (= Syr II) and 155 (= Syr. III), HTR 59/1966, s. 265-268.

7 M. S. S m i th, How to Write a Poem, s. 196-197.

8 D. A m a r a, די סוטסקט, טיעבשה םוגרתב 151 רומזמ ויבל וניב סחיהו וארמוקמ אנק רומזמ ,הראמע הכ-טי, (חנשת)

9 J. A. S a n d e r s, Psalm 151 in 11QPss, ZAW 75/1963, s. 73-86.

11) T e n ż e, The Psalms Scroll.

$"$ Tamże, s. 63; A. T r o n i n a także odnotowal, że skrócenie doprowadziło do utraty sensu trzeciego wersetu w wersji Septuaginty: t e n ż e, Psalm 15 - poetycki midrasz do dziejów Dawida, RT 43/1996, s. 85.

12 Tamże, s. 84 (badacz odnotowuje, że w wersji greckiej istota psalmu nie jest jasna, a dwa ostatnie wersety wydają się dołączone sztucznie); J. C. V a n d e r K a m, P. W. F l i n t, The Meaning of the Dead Sea Scrolls: Their Significance For Understanding the Bible, Judaism. Jesus, and Christianity, San Francisco 2002, s. 189; D. J. H a r r in g t o n, Invitation to the Apocrypha, Grand Rapids 1999, s. 171-172; Harrington nazywa wersję grecką "nieco niezladną" (somewhat clumsy).

${ }_{13}$ Z wyjątkiem chyba J. S t r u g n e II a. Badacz odnotowuje w greckim przekładzie kilka

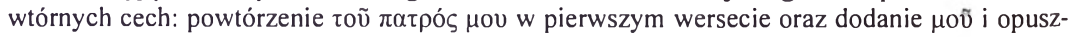
czenie $\pi \alpha ́ v \tau o v$ w trzecim wersecie; t e n ż e, Notes on the Text, s. 267. Zresztą te cechy można przypisać właśnie greckiemu przekładowi, a nie jego Vorlage.

${ }_{14}$ J. A. S a n d e r s, The Qumran Psalms Scroll (l1QPs $\left.{ }^{a}\right)$ Reviewed, w: M. B I a c k, W. A. S m a I I e y (red.), On Language, Culture and Religion: in Honour of Eugene A. Nida, The Hague 1974, s. 85. 
Przeciwny punkt widzenia wyrażają przede wszystkim M. Haran, M. Segal i M. S. Smith. B. Z. Wacholder także popiera ich krótką uwagą o przypuszczalnej pierwotności Vorlage Septuaginty. ${ }^{15}$ Badacze przytaczają jako dowód na rzecz swojego zdania nieco więcej faktów. M. Haran zwrócił uwagę na to, że znaczna część tych słów i wyrazów, których brak w przekładzie greckim, należy do późniejszego języka niż te, które znajdują się w przypuszczalnym Vorlage Septuaginty. ${ }^{16}$ Później M. S. Smith ponownie opublikował listę tych wyrazów uzupełniwszy ją i opatrzywszy krótkimi komentarzami. ${ }^{17}$

Jednym z argumentów zwolenników hipotezy J. A. Sandersa jest niejednokrotnie podkreślana logiczna struktura obszernej redakcji ${ }^{18}$ mimo że argument ten jest sprzeczny z zasadą lectio difficilior potior. W tej kwestii jednak nie można nie wspomnieć R. Stichela, który w przeciwieństwie do tego dowodu poddał analizie grecki tekst psalmu i także wykrył w jego kompozycji nie mniej logiczną, chociaż nie tak oczywistą strukturę..$^{19}$

Co zaś do treściowej różnicy między dwoma wersjami, tę kwestię rzadko poruszano w pracach poświęconych psalmowi. ${ }^{20} \mathrm{~J}$. A. Sanders odnotowuje tylko, że krótsza wersja powstała w wyniku nałożenia na oryginał elementów kultury hellenistycznej. ${ }^{21}$ Ciekawa z tego punktu widzenia wydaje się obserwacja I. Š. Šifmana, który uważa, że krótsza wersja odzwierciedla przesunięcie akcentów ideowych, ponieważ

is Z. W a c h o I d e r, David's Eschatological Psalter: 11QPsalms ${ }^{a}$, HUCA 59/1988, s. 59-60.

16 M. H a r a n, The Two Text-Forms in Psalm 151, JJS 39/1988, s. 176. D. Amara wskazuje na to, że przypuszczalne Vorlage Septuaginty także zawiera jedną cechę późnego języka, mi-

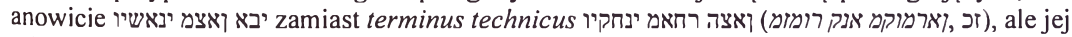
rekonstrukcja hebrajskiego Vorlage psalmu wydaje się niezbyt przekonywająca.

17 M. S. S m i t h, How to Write a Poem, s. 196-197. Podobne stanowisko zajmuje S. T a Im o n, ale on uważa za późniejszy dodatek tylko część hymniczną; t e n ż e, Extra-Canonical Hebrew Psalms from Qumran - Psalm 151, w: t e n ż e (red.), The World of Qumran from Within: Collected Studies, Leiden 1990, s. 252-253. Segal zaś ograniczył się do powołania się na pracę Harana: M. S e g a I, The Literary Development of Psalm 151: A New Look at the Septuagint Version, Textus 21/2002, s. 154.

18 A. K o w a I s k i, Psalmy 151-155 (Syryjskie psalmy apokryficzne 1-5), WST 7/1995,

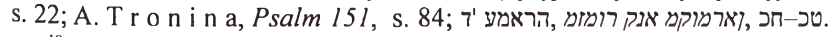

19 R. S t i c h e l, Beiträge, s. 336-337. Także chiazm w tekście greckim upatruje M. S e g a l, ale jego zdaniem ta konstrukcja obejmuje tylko pierwsze pięć wersetów; t e n ż e, The Literary Development, s. 153.

${ }^{20} \mathrm{~J}$. M a g n e np. twierdzi, że celem skrócenia byla, aby próba w sposób prozaiczny przekazać treść psalmu niczego nie opuściwszy, dlatego między dwoma wersjami nie ma żadnych różnic dogmatycznych; t e n ż e, Les textes grec et syriaque du Psaume 151, RevQ 8/1975, s. 563.

21 J. A. S a n d e rs, The Psalms Scroll, s. 717. 
brak w niej jakiejkolwiek roli kapłanów w wybraniu króla, samo zaś wybranie Dawida okazuje się źle uzasadnione. ${ }^{22}$ Najbardziej pełny opis różnic między treścią dwóch wersji przedstawił M. Segal. ${ }^{23}$

Data tłumaczenia także pozostaje niejasna. Sytuacja jest jeszcze bardziej skomplikowana przez to, że nie mamy oryginału hebrajskiego, z którego prawdopodobnie przetłumaczono psalm na język grecki. J. A. Sanders ogranicza się do krótkiej uwagi, że Pierwsza Księga Machabejska (I w. p. n. e. wg Sandersa) prawdopodobnie cytuje Psalm 78, nie możemy jednak być pewni, że w tych czasach Ps 151 już został włączony do kanonu Septuaginty. ${ }^{24} \mathrm{M}$. Haran uważa, że przekład Septuaginty powstał nie później niż w II w. p. n. e. ${ }^{25}$

Hebrajski tekst Psalmu 151A w 11Q5 wygląda następująco:

Alleluja Dawida, syna Jessego.

Mniejszy od mych braci byłem

I młodszy od synów mego ojca.

Ustanowił mnie pasterzem swej trzody

I władcą nad swymi kozłami.

Moje ręce zrobili flet,

I me palce lirę.

Oddałem chwałę Panu.

Powiedziałem w (głębi) duszy:

Góry nie świadczą dla mnie

I wzgórza nie głoszą o mnie,

Drzewa moich słów,

I trzoda moich czynów.

Zatem któż ogłosi i któż oznajmi,

Któż opowie o dziełach moich?

Pan wszechświata zobaczył,

Bóg wszystkiego.

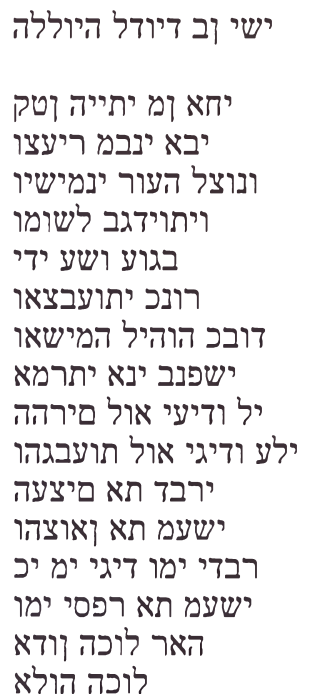

22 И. Ш. Ш и фм а н, Псалом 15l, s. 148-149.

23 Zdaniem badacza, do tych zmian, które powstały podczas rozszerzenia oryginalnej krótszej wersji tekstu należą: przemienienie Dawida z wykonawcy muzyki świeckiej w poetę religijnego, idea niemożliwości wychwalania Pana przez przyrodę oraz dodanie wielu motywów biblijnych związanych z królestwem i rządami Dawida; M. S e g a I, The Literary Development, s. 155-157.

${ }_{24}$ J. A. S a n d e r s, The Psalms Scroll, s. 59.

${ }_{25}$ M. H a ra n, The Two Text-Forms, s. 178. S. O I o f s s o n odnosi thumaczenie calego Psalterza do II w. p. n. e.; t e n ż e, Qumran and LXX, w: F. H. C r y e r, T. L. T h o m p s o n (red.), Qumran between the Old and New Testaments, JSOTSup 290, Sheffield 1998, s. 235-236. 
(Właśnie) on usłychał

I (właśnie) on wysłuchał.

Posłał swego proroka, by mnie namaścił, Samuela, Samuela, by mnie uczynił wielkim.

Moi bracia wyszli mu naprzeciw,

Urodziwi i przystojni,

Wysokiego wzrostu,

O pięknych włosach.

Nie wybrał Pan

Bóg ich,

Lecz posłał, by mnie zabrano od trzody,

I namaścił mnie świętym olejem.

Ustanowił mnie przywódcą swego ludu

I władcą nad synami swego przymierza. ${ }^{26}$

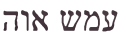

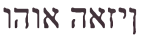

ינחשומל ואיבנ חלש אותו

ינלדגל לאומש תאיבנ חלש

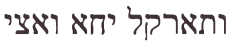

הארמה יפיו רותה יפי מוזי

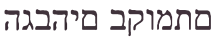

מרעשב םיפיה מיהגה

הוהי רחב אול מיפיה

םב פיהולא רולא

ואוצה רחאמ ינחקיו חלשיו

שדוקה ומשב ינחשמיו

ומעל דיגנ ינמישיו ינחמיו

27ותירב ינבב לשומנו ינמון

Vorlage greckiego przekładu Ps 151,1-5 powinno wyglądać następująco:

Byłem najmniejszy z braci moich

יחאב יתייה ןטק

I najmłodszy w domu ojca mego.

יבא תיבב ריעצו

Pasałem trzodę ojca mego.

Moje ręce zrobiły flet,

A moje palce sporządziły lirę.

I któż ogłosi Panu memu?

ונאצ תא יתיער ריעצ

בגוע ושע ידי יתי

רונכ וננכ יתעבצא רשעי ידי

(Właśnie) on jest Panem,

ינדאל דיגי ימנכ יתוא

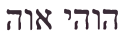

${ }^{26}$ Ten przekład opiera się na tłumaczenu P. M u c h o w s k i, Rękopisy znad Morza Martwego: Qumran - Wadi Murabba'at - Masada - Nachal Chewer, Biblioteka zwojów: Tło Nowego Testamentu 5, Kraków 2000, s. 442.

27 Tekst wydany przez Sandersa został kilkakrotnie poddany krytyce. W rękopisie 11Q5 litery $\mathrm{i}$ i ' wyglądają w bardzo podobny sposób, także tekst psalmu jest zapisany jako proza, bez podziału na wiersze. Zdaniem niektórych badaczy, doprowadziło to Sandersa do blędnego odczytania niektórych fragmentów psalmu. Przedstawiony tu tekst nieco różni się od wydanego przez Sandersa i jest wynikiem naszych badań; zob. A. А. Ф а р у т и н, K воnросу о различных возможностях прочтения еврейского текста Псалма 151 в рукописи $11 Q 5$, ш: И. Р. Т а н т л е в с к и й (ред.), Иудаизм эпохи Второго Храма, раннее христианство и античность (взаимодействие в истории, литературе и культуре и отражение этого периода в культурной памяти Средних веков и Нового времени, Санкт-Петербург 2013. Także nasze rozumienie tego tekstu zbiega się z wersjami P. A u f f r e t a, Structure littéraire et interprétation du psaume 151 de la grotte 11 de Qumrân, RevQ 34/1976-1977, s. 163-188 i D. A m a r y (וארמוקמ אנק רומזמ, הראמע '7). 
(Wlaśnie) on usłyszał.

(Właśnie) on posłał posłańca swojego

I zabrał mnie od owiec.

I namaszczył mnie swoim olejem namasz-

czenia.

Bracia moi są piękni i rośli,

Ale Pan nie upodobał w nich sobie.
עמש אוה

וכאלמ חלש אוה

ואצה רחאמ ינחקיו

ותחשמ ןמשב ינחשמיו ינחיו

םילדגו םיפי יחא

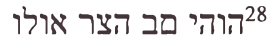

\section{Lista przedstawiona przez M. S. Smitha}

Jak już powiedziano wyżej, w 1997 r. M. S. Smith wydał ponownie z komentarzami i uzupełnieniami uzyskaną wcześniej przez M. Harana listę wyróżniających cech tekstu qumrańskiego, które te cechy mogłyby świadczyć o jego wtórności. Ta lista w ostatecznej redakcji wygląda następująco:

- יחא || יבא ינב

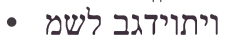

- מיש w znaczeniu ,oddawać (chwałę)”

- שפנב ...רמא הולא שיש

• לוכה ןודא || לוכה הולא לאמא

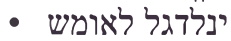

- הארמה יפיו רותה יפומל יפיפי

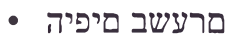

• ותירב ינבעב מיפיה

Należy rozpatrzyć tę tezę na podstawie istniejących źródeł literackich. Pierwszy punkt $\mathrm{z}$ tej listy można $\mathrm{z}$ całą pewnością odrzucić. M. S. Smith mówi, że pojawiająca się w psalmie para יחא || יבא ינב (,bracia moi” || „synowie ojca mego") jest innowacją autora, która wygląda jak zamiana standardowego biblijnego (מא ינב || םיחא (,bracia” \| ,synowie matki”). M. Haran także przytacza listę fragmentów, w których pojawia się konstrukcja zachowana w przekładzie greckim: יחא biblijna" niezbyt często pojawia się w Starym Testamencie. ${ }^{30}$ Jednak

\footnotetext{
${ }^{28}$ Niestety, w ramach danego artykułu nie ma żadnej możliwości przytaczania wszystkich dowodów na rzecz właśnie takiej rekonstrukcji. Możemy tylko odesłać do naszej pracy magisterskiej: A. А. Ф а р у т и н, Текст Псалма 151 в рукописи $11 Q 5$ и переводе Септуагинты, Санкт-Гетербургский государственный университет 2012, s. 58-80.

29 M. H a r a n, The Two Text-Forms, s. 174-175.

30 Rdz 27,29; 43,29; Pwt 13,7; Sdz 8,19; Ps 50,20; 69,9; por. także PnP 8,1: י - „mój brat” || ,który ssał pierś mojej matki”.
} 
decydującym argumentem przeciwko temu, by uważać qumrański wyraz za nowość, jest jego użycie w Księdze Rodzaju. ${ }^{31}$ Nie można w tym miejscu nie odnotować, że para pojawiająca się w przekładzie greckim jest znacznie bardziej powszechnie używana.

Potem Haran wskazuje na dziwność wyrazu ויתוידגב לשומו (,,i [ustanowił mnie] władcą nad swymi kozłami") mówiąc, że w tekście biblijnym czasownik לשמ (,rządzić, kierować”) ma jako dopełnienie tylko ludzi, grupy ludzi albo ziemie i nigdy nie opisuje stosunków między pasterzem i jego bydłem. ${ }^{32}$ Ten argument wydaje się niezbyt przekonywający z kilku względów. Po pierwsze, analiza użycia niektórych leksemów służacych do oznaczenia bydła i oddzielnych zwierzęt domowych ${ }^{33} \mathrm{w}$ tekście biblijnym pokazuje, że poza czasownikiem הער (,paść") $)^{34}$ brak w języku biblijnym ustalonego sposobu wyrażenia idei dozoru nad zwięrzętami, któremu to sposobowi można byłoby przeciwstawić „niezwykły” leksem לשמ. powodu autor psalmu mógł czuć się stosunkowo swobodnie w wyborze poetyckiego synonima dla הער. Po drugie, chociaż czasownika

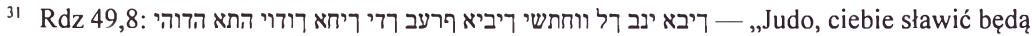
bracia twoi, twoja bowiem ręka na karku twych wrogów! Synowie twego ojca będą ci oddawać pokłon”; por. także 1Krl 1,9 (דלמ ינב || - „יחא -,bracia” || „synowie króla”). Ciekawe, że Haran odnotowuje, że tej pary brak w języku biblijnym; zob. M. H a r a n, The Two Text-Forms, s. 174.

32 Tamże, s. 175. Autor także wymienia dwa przypadki nie włączone do jego schematu: w Ha 1,14 czasownika użyto wobec gadów, ale w tym przypadku one są metaforycznym wizerunkiem ludzi (poza tym, z tym rzeczownikiem użyto przyimka $\supset$ - ,jak"), a w Rdz 1,18 — wobec dnia i nocy, ale to też jest barwna metafora unikalna dla tekstu biblijnego. To, że czasownika prawdopodobnie użyto przez analogię do ותירב ינבב לשומו (,i [ustanowił mnie] władcą nad synami swego przymierza”) w ostatnim wersecie, M. Haran nie uważa za przekonujący argument przeciwko jego niewłaściwości w tym przypadku.

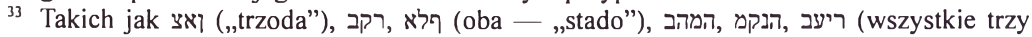

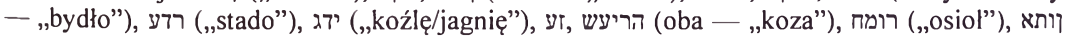

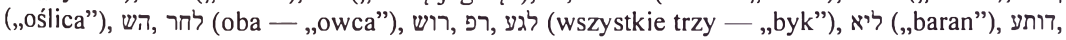

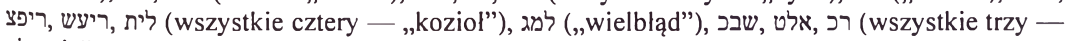

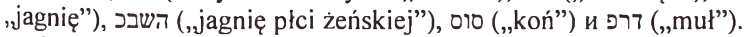

${ }_{34}$ Por. Rdz 4,2; 13,7 (2 razy); 30,31; 36, 24; 37,2. 12; 46, 32. 34; 47,3; 1 Sm 16,11; $17,15$. 34 (ostatnie trzy są z historii Dawida); 25,16; Iz 40,11; 61,5; 63,11; Jr 23,2, 34,2. 3. 8. 10. 15; Mi 7,14; Oz 4,16 (pośrednio); Za 11,4. 7 (2 razy); PnP 1,8 (jedyny przypadek użycia tego typu z rzeczownikiem הידג*) pojawiającym się w tekście psalmu.

3s Wskazane znaczenie nieregularnie wyraża się w absolutnie różne sposoby. Wśród nich należy wymienić: czasownik רמש (,strzec”): Rdz 30,31; Jr 31,10 (pośrednio); wyrazy (היה) רע (היה),

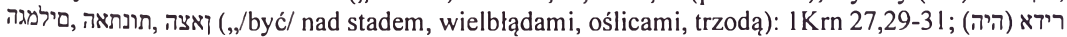

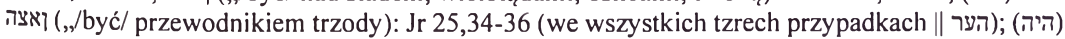

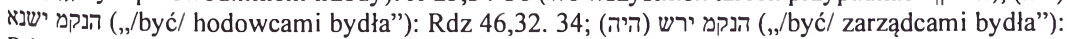
Rdz 47,6. Także por. podobne wyrazy: רדעל בל תיש i (,troszczyć się o trzodę") cać uwagę na bydło"): Prz 27,23; רדעב עדנ (dosłownie ,pędzić bydło”): Jr 31,24 itd. 
לשמ rzeczywiście używa się w zasadzie ze słowami oznaczającymi ludzi i ziemię, ${ }^{36}$ leksem ten mimo wszystko okazuje większą wieloznaczność, niż wskazał M. Haran, ${ }^{37} \mathrm{i}$ w dwóch przypadkach użyto go w kontekście dość bliskim do naszego, mianowicie w sytuacji, gdy starszy powołuje młodszego na dozorcę majątku. ${ }^{38}$ Tak więc, nie możemy uważać użycie czasownika לשמ w tym przypadku za całkiem niezwykłe. Gdyby w tekstach qumrańskich czasownika często używało się w znaczeniu ,zarządzać bydłem”, mogłoby to wskazywać na późny rozwój tego znaczenia, ale nie obserwujemy nic podobnego w rękopisach znad Morza Martwego. ${ }^{39}$

${ }_{36}$ Rdz 3,16; 37,8; 45,26; Pwt 15,6 (2 razy); Joz 12,2.5; Sdz 8,22. 23 (3 razy); 9,2 (2 razy); 14,$4 ; 15,11 ; 2 \mathrm{Sm} \mathrm{23,3;} \mathrm{Krl} 5,1 ; 2 \mathrm{Krn} 7,18 ; 9,26 ; 20,6 ; 23,20 ;$ Ne 9,37; Ps 19,14; 22,29; 59,14; 105,$20 ; 106,41 ; \operatorname{Prz} 17,2 ; 19,10 ; 22,7 ; 28,15 ;$ Koh 9,17; Iz 3,4.12;16,1; 19,4; 28,14; 52,5; 63,19; Jr 22,30; 30,21; Lm 5,8; Dn 11,39; Mi 5,1; Za 9,10; por. także Ha 1,14.

37 Oprócz przypadku Rdz 1:18 czasownika używa się z תאט (,grzech”): Rdz 4,7; bezokolicznikiem רכמל (,",nie władny/ sprzedać”): Wj 21,8; לכ (,wszystko”): 1Krn 29,12; Ps 103,19; טידי ישעמ (,dzieła rąk”): Ps 8,7; חיה תואג (,pyszność morza”): Ps 89,10; (panować nad) duchem = (panować nad) sobą”): Prz 16,32; ףסכהו בהזה ינמכמ (,/opanować/ skarby złota i srebra”): Dn 11,43. Także w znacznej liczbie przypadków czasownika użyto bez dopełnienia: Lb 21,27; 2Sm 23,3; Hi 25,2; Ps 66,7; Prz 6,7, 12,24, 23,1, 29,2, 12, 26; Koh 10,4; Iz 14,15, 40,10, 49,7; Jr 33,26, 51,46 (2 razy); Ez 19,11, 14; Dn 11,3, 4 (2 razy), 5 i Za 6,13.

${ }_{38} \mathrm{Rdz} 24,2$ : ודבע -...,jego (Abrahama) sługa /.../ zarządzający wszyst-

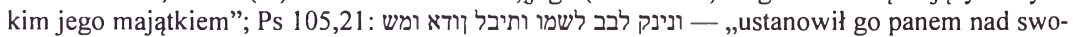
im domem i władcą nad całą swoją posiadłością". Same z siebie te fragmenty nie mogą świadczyć bezpośrednio przeciwko dowodom M. Harana, ponieważ לשמ tu także ma jako dopelnienie słowa nie związane z bydłem. Jednak, po pierwsze, wydaje się, że zarówno wyraz ול רשא לכ, jak i słowo וינק obejmują pewne zwierzęta domowe, po drugie zaś, w/w użycia czasownika należy rozpatrywać razem z pierwszym argumentem: nie mając standardowej pary dla הער autor psalmu mógł wybrać słowo wychodząc z tych podobnych kontekstów - zwłaszcza Ps 105,21, gdzie imiesłowu לשמ użyto z tym samym czasownikiem מיש (ustanawiać) w tej samej formie: ינמישיו.

39 Zob. M. G. A b e g g i in., The Dead Sea Scrolls Concordance: The Non-Biblical Texts, Leiden 2003, s. 491--492. Teksty qumrańskie także przedstawiają pewną wariacyjność użycia czasownika. Większość przykładów użycia tak samo, jak w Starym Testamencie, przypada na wskazaną przez Harana ideę zarządzania ziemiami (w tym całym wszechświatem) i ludźmi: CD XII,2; IQS IX,22; IQpHab IV,5, 10, 12, V,13, VIII,9; 1QH ${ }^{a}$ V,2I, XVIII,8; 4Q161 8-10,2; 4Q169 1-2,5a, 7, 3-4i3; 4Q223-224 1i2, 1i3; 4Q256 XVIII,6; 4Q258 VIII,7; 4Q271 5il8; 4Q369 lii7; 4Q378 3ill; 4Q381 1,7; 4Q385a 4,4; 4Q387 2ii6; 4Q390 1,3, 1,1, 2i7, 4Q415 9,8; 4Q416 2il9, 2iiil7, 2iv2, 3, 6; 4Q418 10a-b,5; 4Q424 3,2; 4Q433 1,3; 4Q524 6-10,2; $11 Q 19$ LIX,15, 19 i 20. Także w znacznej liczbie przypadków dopelnienie czasownika utracono, lub było jego brak od początku: 1QSb V,28; 1QH ${ }^{\mathrm{a}}$ VI,28; $2 \mathrm{Q} 23$ 6,3; 4Q169 3-4ii9; 4Q287 4,2; 4Q299 13a-b,2, 26,1, 4Q301 2a,3; 4Q381 76-77,15; 4Q391 64,1; 4Q416 2iv7; 4Q417 2il3; 4Q418 9+9a-c,12, 18, 228,2, 259,2; 4Q418a 18,4, 22,2; 4Q419 4,1; 4Q421 laii-b,6; 4Q423 5,3; 4Q424 2,5, 3,6; 4Q443 1,11; 4Q462 I,7, 10; 4Q502 4,4; 4Q504 8,6; 4Q509 191,4 i 6Q18 6,3. Jednak w zwojach znad Morza Martwego także pojawiają się "niestandardowe" dopelnienia. W kilku kontekstach czasownika לשמ używa się z bezokolicznikiem i przyimkiem ל w znaczeniu „móc, być w stanie coś zrobić” (por. Wj 21,8): CD XIII,12; 4Q418 10a- 
Jako następny na liście M. S. Smitha figuruje czasownik מיש w znaczeniu „oddawać (chwałę)”. Tezę o późniem lub „sztucznym” pochodzeniu tego wyrazu ${ }^{40}$ można wytłumaczyć tylko niewystarczająco dokładnym zbadaniem tekstu Starego Testamentu, ponieważ ten wiersz ma bezpośrednie odpowiedniki w Joz 7,1941 i Iz 42,12,42 i jeśli drugi tekst datuje się na dość późny okres ${ }^{43}$, starożytność pierwszego nie ulega wątpliwości. ${ }^{44}$

Dalej M. S. Smith zwraca uwagę na użycie w tekście konstrukcji שמנב רמא. Jej niezwykłość podkreślano niejednokrotnie. ${ }^{45} \mathrm{~W}$ rzeczywistości, jak słusznie wskazuje Smith, ten wyraz służy jako odpowiednik standardowego biblijnego בבלב/בלב רמא (dosłownie „mówić w sercu (swym)”). ${ }^{46}$ Tylko jeden raz, w tekście Księgi Estery

-b,8 i 4Q422 1,9. Także czasownika użyto z następującymi słowami: טפשמה (,sąd” i ,ma-

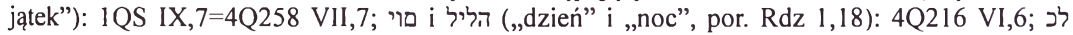

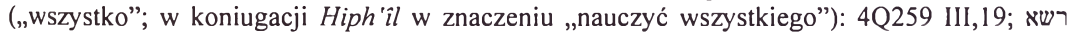

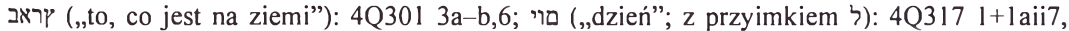

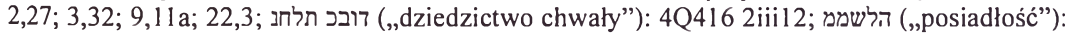

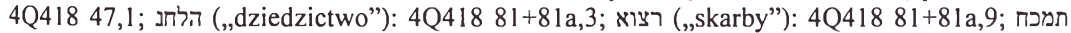

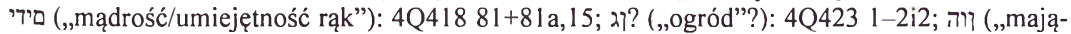
tek”): 4Q424 1,10; חור (,duch”; kontekst nie jest do końca jasny z powodu złego stanu rękopisu, ale por. Prz 16,32): 4Q425 5,3. Warto zwrócić uwagę na to, że wśród tych przykładów są dwa przypadki użycia czasownika לשמה ze słowem (,majątek”) podobne do Rdz 24, 2 i Ps 105,21.

${ }_{40}$ M. S. S m i t h uważa, że mogło ono powstać pod wpływem „bardziej standardowego" użycia czasownika w wierszu 1IQ5 XVIII 11; t e n ż e, How to Write a Poem, s. 197.

41 Rzekł więc Jozue do Akana: „Synu mój, daj chwałę Panu, Bogu Izraela...”.

42 Niech oddają chwałę Panu i niechaj głoszą cześć Jego na wyspach!" Por. także kilka fragmentów o podobnym znaczeniu lub konstrukcji składniowej: „Niech (Pan) zwróci ku tobie oblicze swoje i niech cię obdarzy

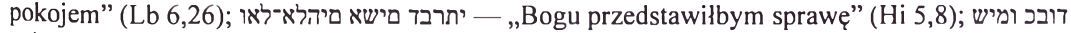
_ „ותלהת _cześć Mu świetną oddajcie” (Ps 66,2).

${ }^{43}$ Jeśli późnym okresem można nazwać okres niewoli babilońskiej; zob. G. B. G r a y, A Critical and Exegetical Commentary on the Book of Isaiah 1-27, ICC 18, New York 1912, s. xxix-xxxii.

${ }_{44}$ D. M. H o w a r d, Joshua, NAC 5, Nashville 1999, s. 29-30.

45 I. R a b i n o w i t z, The Alleged Orphism of 11QPss 28 3-12, ZAW 76/1964, s. 197;

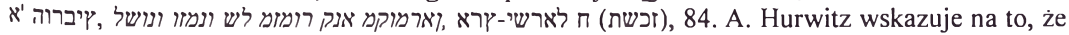
ten wyraz występuje w języku syryjskim i Talmudzie Jerozolimski, co świadczy o tym, że jest to późniejszy arameizm; tamże.

46 Do wymienionych przez M. S. Smitha fragmentów Koh 2,1; 3,17; Ps $14,1=53,2$ należy także dodać Rdz 17,17; 27,41; Pwt 7,17; 8,17; 9,4; 18,21; $1 \mathrm{Krl} 12,26$; Est 6,6; Ps 4,5; 10,6; 11,13; 35,25; 74,8; Koh 2,15; 3,18; Iz 14,13;47,8.10;49,21; Jr 5,24; 13,22; Ab 1,3; So 1,12; 2,15; Za 12,5. Pod tym względem należy także koniecznie wymienić nadzwyczaj podobne wy-

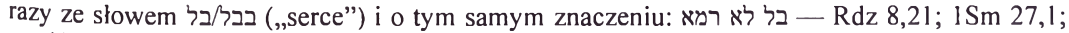

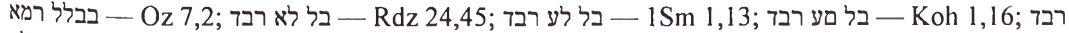

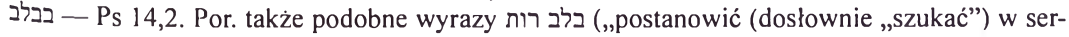


ימדת־לא :שפנ רשפנב (,nie myśl sobie w [głębi] duszy”). Wyraz ten jest jednak dość daleki od tego, co widzimy w psalmie, ponieważ nie zawiera on słów רבד lub (,mówić”) i po nim pojawia się nie mowa niezależna, lecz bezokolicznik z przyimkiem ל. Poza tym, wyraz ten i w tym przypadku wydaje się nieco „sztuczny” w porównaniu ze swoim nadzwyczaj często pojawiającym się $\mathrm{w}$ tekstach $\mathrm{z}$ różnych okresów io różnym charakterze (w tym w Est 6,6) odpowiednikiem. Szczególnie należy zauważyć, że בבלב/בלב (רבד) רמא dość często spotykamy w tekście Psałterza (siedem razy). W tekstach z Qumran jeden raz spotykamy wyraz בבלב רמא po którym występuje mowa niezależna. Wydaje się, że podobne wyrazy ze słowem שפנ w zwojach znad Morza Martwego się nie zachowały. ${ }^{48}$ Tylko jeden raz grecki wyraz $\lambda \dot{\varepsilon} \gamma \omega \dot{\varepsilon} v \tau \tilde{\eta} ~ \psi v \chi \tilde{\eta}$ („mówić w [głębi] duszy”) pojawia się w Syr 23,18, ale hebrajskie Vorlage tej części tekstu nie zachowało się ani wśród rękopisów z genizy kairskiej, ani w Qumran. ${ }^{49} \mathrm{~W}$ ślad za A. Hurwitzem powinniśmy uważać ten wyraz za późniejszy arameizm, ${ }^{50}$ który zaczął wchodzić do języka hebrajskiego w okresie pobiblijnym.

Jako następne na liście M. S. Smitha występują paralelne wyrazy לוכה וודא (,Pan wszystkiego”) i לוכה הולא (,Bóg wszystkiego”). Późne pojawienie się i użycie tych wyrazów nie ulega wątpliwości, ${ }^{51}$ nie

cu”) - בבלב דרבתה (,poh 2,3phlebiać sobie w sercu”) - Pwt 29,18; בבלב בשח (,zamierzać w sercu") - Za 7,10,8,17. Koniecznie trzeba odnotować, że w wielu przypadkach, gdy postacie biblijne mówią cokolwiek prawdopodobnie w myśli, w tekście hebrajskim używa się tylko czasownika רמא bez dopełnienia dalszego. Często pojawia się to w opowieściach etiologicznych (Rdz 16,13; 29,32; 33,35 etc.) oraz w Rdz 32,20; 44,28; Wj 2,6; Lb 16,34; Pwt 28,67; 1 Krn 19,2; Hi 7,4. 13; 32,7; Ps 39,2; Prz 22,13; Jr 10,19 itd. Podobny wyraz pojawia się także w greckich wersjach apokryfów starotestamentalnych (z punktu widzenia kanonu masoreckie-

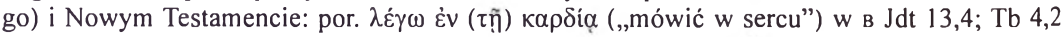

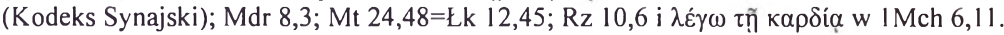

47 IIQ19 LXI,2. Należy także odnotować użycie w 4Q372 8,4 wyrazu בבלב ויבה (,rozumieć/zastanawiać się w sercu"), ale z powodu złego stanu w/w fragmentu nie możemy odtworzyć kontekstu i ustalić, na ile ten wyraz jest bliski do בבל/בלב רמא.

48 M. G. A b e g g i in., The Dead Sea Scrolls Concordance, s. 516-518.

49 Zob. B. G. W r ig h t, Ben Sira, Book of, w: L. H. S c h if f m a n, J. V a n d e r K a m, Encyclopedia of the Dead Sea Scrolls, Oxford 2000, s. 92.

50) Por. użycie tego wyrazu w języku syryjskim odnotowane w: J. P a y n e $\mathrm{S}$ m i t h, A Compendious Syriac Dictionary: Founded Upon the Thesaurus Syriacus of Robert Payne Smith, Oxford 1957, s. 347.

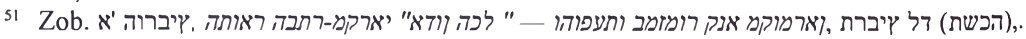
A. Hurvitz zwraca uwagę na to, że tego epitetu używa się w późniejszych tekstach: Hi 5,8 w przekładzie Septuaginty (zamiast samego (מיהולא (,Bóg”) w tekście masoreckim), w niektórych tekstach syryjskich, tekstach z Palmyry, Talmudzie Babilońskim, modlitwach, niektórych 
można jednak nie odnotować, że odczytanie fragmentu tekstu zawierającego te wyrazy jest sporne (J. A. Sanders rozumie ten fragment w zupełnie inny sposób), więc nie można ich nazwać w pełnej mierze ważkim argumentem. Także M. S. Smith słusznie zauważył, ${ }^{52}$ że paralelizm epitetów וודא i הולא pojawia się i w Starym Testamencie w Ps 114,7 .

Dalej badacz zwraca uwagę na niezwykłe użycie w tekście czasownika לדג w koniugacji $P i^{\prime}$ 'él. Jeszcze Haran wskazywał ${ }^{53}$ na to, że w tym przypadku ten wyraz powstał pod wpływem aramejskiego czasownika יבר', który oznacza nie tylko „wywyższać”, lecz także „namaszczać”, „ustanawiać”. ${ }^{54}$ Należy odnotować, że w języku biblijnym czasownik לדג jest dość wieloznaczny ${ }^{55}$ i w kilku przypadkach używa się go w znaczeniu nieco podobnym do tego, które przypuszczamy w tekście psalmu. ${ }^{56}$ ale największe podobieństwo pojawia się, gdy użyto go z różnego rodzaju okolicznikami. ${ }^{57}$ Poza tym, wydaje się, że w parze z czasownikiem חשמ (,namaszczać”) w tym przypadku powinniśmy spodziewać się właśnie czasownika oznaczającego obdarzenie władzą krolewską w rodzaju hebrajskiego רילמה (,ustanawiać królem"). ${ }^{58}$ Ten fakt może dodatkowo świadczyć, że czasowni-

tekstach greckich. Także badacz wskazuje na użycie terminu לוכה הולא („Bóg wszechświata”) w hebrajskim tekście Mądrości Syracha.

${ }_{52}$ M. S. S m i t h, How to Write a Poem, s. 196-197.

53 M. H a r a n, The Two Text-Forms, s. 176. Na to wskazuje także A. H u r v i t z, איברוה ', נושל.

${ }_{54}$ M. S o k o I o f f, A Dictionary of Jewish Palestinian Aramaic of the Byzantine Period, Ramat Gan 1992, s. 514; M. J a s t r o w, Dictionary of the Targumim, the Talmud Babli and Yerushalmi, and the Midrashic Literature, New York 1903, s. 1441.

is Często w $P_{i}{ }^{\prime \prime}$ èl czasownika się używa w znaczeniu „wychowywać/hodować”. Tak się mówi o dzieciach: Iz 1,2; 23,4; 49,21; 51,18; Dn 1,5; Oz 9,12; roślinach: Iz 44,14; Ez 31,4; Jon 4,10; włosach: Lb 6,5. Czasownika używa się i w znaczeniu „wywyższać Pana”: Ps 34,4 (z przyimkiem ל), 69,31. W połączeniu z różnego rodzaju rzeczownikami czasownik także

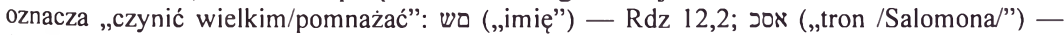
IKrl 1,37, לכ לכ (,wszystko”) - החמש IKrn 29,12 (,radość”) - Iz 9,2.

${ }_{56}$ Trochę przypomina nasz przypadek użycie w B Est 3,1; 5,11 i 10,2 (Aswerus wywyższa Hamana i Mardocheusza) oraz Hi 7,17 (Pan wywyższa człowieka).

57 Nadzwyczaj podobne do tekstu psalmu są fragmenty Joz 3,7 i 4,14 (Pan wywyższa Jozuego) oraz I Krn 29,25 i 2Krn 1,1 (Pan wywyższa Salomona). Ale w ostatnich dwóch przypadkach znaczną rolę gra okolicznik הלעמל (,wysoko”), w pierwszych zaś dwóch - סיניעב (,w oczach”), dlatego przeprowadzenie ścisłej paraleli z tekstem psalmu nie wydaje się możliwe.

${ }^{58}$ Tak w 2 Krn 23,11. Jest to, niestety, jedyny przypadek, gdy w Starym Testamencie kon-

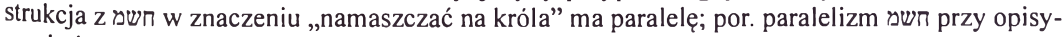
waniu kapłaństwa z שידי אלמ (doslownie „,napelniać ręce”) w Wj 28,41; 30,30; 40,13; Kpl 16,32 i Lb 3,3. 
ka לדג użyto w psalmie właśnie w późnym znaczeniu „namaszczać”, którego to znaczenia odpowiednik możemy znaleźć tylko w języku aramejskim.

$\mathrm{Za}$ jeszcze jedną wyróżniającą cechę tekstu qumrańskiego M. S. Smith uważa wyraz הארמה יפיו רותה יפי (,urodziwi i przystojni”). Według badacza, jest to zmienione pod wpływem frazeologii biblijnej (,przystojny” - 1Sm 17,42) lub הארמ הפי בוטו מיניע הפי (,mający piękne oczy i pociągający wygląd" — 1Sm 16,12). Wydaje się jednak, że jest to zupełnie biblijny wyraz, który wszedł do tekstu nie z historii Dawida, lecz z Rdz 29,17 lub 39,6.59

מרעשב םיפיה Niezwykły wydaje się M. S. Smithowi także wyraz („o pięknych włosach”). Rzeczywiście nie spotykamy dokładnie takiej frazy w Starym Testamencie, ale są bardzo podobne konteksty, w których precyzuje się, o czego piękno chodzi ${ }^{60}$ Jeśli abstrahować od konstrukcji składniowej, należy odnotować, że włosy można było

59 W tych fragmentach spotykamy absolutnie identyczne wyrazy: o Racheli w Rdz 29,17 (הארמ תפיו ראת־תפי) i o Józefie w Rdz 39,6 (הארמ הפיו ראת הפי).

60 Co do użycia słowa הפרמ (,piękny”), w Starym Testamencie w większości przypadków albo nie ma ono rekcji (Rdz 12,14; $2 \mathrm{Sm} \mathrm{13,1;14,25;} 1 \mathrm{Krl} \mathrm{1,3,4;} \mathrm{Hi} \mathrm{42,15;} \mathrm{Ps} \mathrm{48,3;} \mathrm{Prz} \mathrm{11,22;}$ Koh 3,11; 5,17; PnP 1,8, 15 (2 razy), 16, 2,10, 13, 4,1, 7, 5,9, 6,1, 4, 10; Am 8,13), albo opowiada o ogólnym pięknie i używa się go wtedy ze słowami הארמ i ראת (oba - „wygląd zewnętrzny”): Rdz 12,11, 29,17, 39,6, 41,2, 4, 18; Pwt 21,11; 1Sm 17,42; 25,3; 2Sm 14,27; Est 2,7 oraz prawdopodobnie Jr 11,16 i 46,20; zob. L. K o e h $\mathrm{l}$ e r, W. B a u m g a r $\mathrm{t}$ n e r, The Hebrew and Aramaic Lexicon of the Old Testament, Leiden 1994-2000, s. 424. Jednak od razu w kilku kontekstach spotykamy także uściślenia nieco podobne do tych, które widzimy w tekście psalmu. Por. פינע הפי („o pięknych oczach”) w 1Sm 16,12, פנע הפי („2 pięknych gałęziach”) w Ez 31,3, ויתוילד ברב ויתישע הפי הפי (ziezyniłem go pięknym obfitością jego gałęzi”) w Ez 31,9

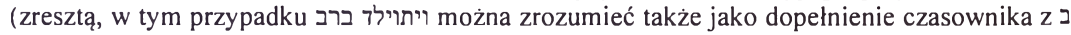

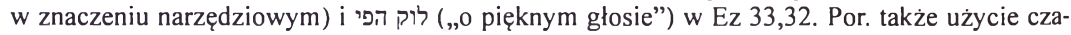

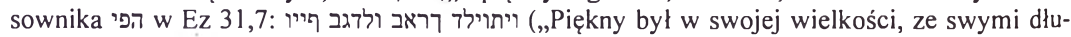
gimi gałęźmi”). W pozostałych przypadkach użycia w koniugacji Qal czasownik nie ma rekcji: Ps 45,3; PnP 4,10, 7,2, 7; Ez 16,13 (znaczna szęść tych kontekstów zawiera koniektury, zob. tamże, s. 423). Słowa יפי (,piękno”) stosuje się prawie zawsze (Est 1,11; Ps 45,12, 50,2; Prz 6,25, 31,30; Iz 3,24, 33,17; Lm 2,15; Ez 16,14, 15, 25, 27,3, 4, 11, 28, 12, 17, 31,8; Za 9,17) bez żadnych uściśleń, ale jeden raz widzimy רתמכח יפי (,piękno twojej mądrości”) — Ez 28,7. Nie można pominąć milczeniem i słowo („dobry, piękny”), które czasami pojawia się w parze w הפי (np. w ISm 16,12). Jeśli tego przymiotnika używa się w znaczeniu „piękny” i uściśla się, to także z reguły za pomocą słów יאר i ראת , הארמ (wszystkie trzy — „wygląd zewnętrzny”): Rdz 24,16;26,7; $1 \mathrm{Sm} \mathrm{16,12;2Sm} \mathrm{11,2;1} \mathrm{Krl} \mathrm{1,6;} \mathrm{Est} \mathrm{1,11;2,2} \mathrm{-} \mathrm{3,} \mathrm{7;} \mathrm{Dn} \mathrm{1,4.} \mathrm{W} \mathrm{Na} \mathrm{3,4}$ spotykamy wyraz תבוט, który także zwykle się rozumie jako „piękna”; zob. np. przeklady Biblii Tysiąclecia, American Standard Version, Biblii Króla Jakuba, Biblii Lutra, F. B r o w n, S. R. D r i v e r, C. A. B r i g g s, The Hebrew and English Lexicon: With an appendix containing the Biblical Aramaic, Peabody 1996, s. 336 oraz tlumaczenie tego wersetu w Septuagincie

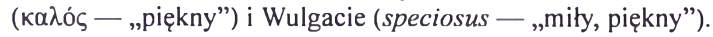


rozpatrywać jako oznakę piękna, przy tym zarówno żeńskiego, ${ }^{61}$ jak i męskiego. Wydaje się, że włosy, jako oznaka piękna mężczyzny, pojawiają się tylko w dwóch fragmentach biblijnych: w opowiadaniu o Absalomie ${ }^{62}$ i w Pieśni nad Pieśniami, ${ }^{63}$ ale $\mathrm{w}$ wymienionych przypadkach tę ideę wyraża się w sposób inny niż w psalmie. Tak więc, wyraz מרעשב מיפיה nie można nazwać zupełnie pozabiblijnym. Należy raczej uważać go za wolną przeróbkę myśli przedstawionej w 2Sm $14,26 .{ }^{64}$

ותירב ינבב Jako ostatni na liście M. S. Smitha pojawia się wyraz (,nad synami swego przymierza”). Badacz porównuje ten wyraz z לוכה וודא i nazywa go niebiblijnym, ale prawdopodobnie należącym do współczesnego autorowi psalmu języka religijnego ${ }^{65} \mathrm{~W}$ tym przypadku analiza tekstów należacych do różnych epok całkowicie podtrzymuje punkt widzenia Smitha. Wydaje się, że w języku biblijnym nie istniało (albo się nie zachowało) określenie narodu za pomocą wyrazu תירב ינב i za podstawowe terminy należy uważać słowa לארשי (,naród”) ל תע (,Izrael”). Za najbardziej bliskie do użytego w psalmie wyrazu należy chyba uważać pojawiające się w Psałterzu konstrukcje $\mathrm{z}$ imiesłowami, ${ }^{66}$ które to konstrukcje są mimo wszyst-

${ }^{61}$ Z pozytywną konotacją w PnP 4,1=6,5; 7,6; Iz 3,24 i Ez 16,7 (w ostatnim przypadku mówi się tylko o tym, że włosy stały się dłuższe, ale ten fakt użyty w parze z opisem piersi widocznie rozpatruje się jako oznakę pozytywną). Zob. także stosunek negatywny w ITm 2,9 i 1 P 3,3.

62 W 2Sm 14,25 powiedziano ראמ ללהל לארשי לכב הפי־שיא היה־אל םולשבאכו (,W calym Izraelu nie było człowieka tak pięknego jak Absalom"), po czym w następnym wersecie widzimy opis jego długich włosów, który tradycyjnie uważa się za jedno z potwierdzeń piękności syna króla; A. B e r l i n, Hair, w: A. A c h t e m e i e r (red.), Harper's Bible Dictionary, San Francisco 1985, s. 367; Hair, w: L. R y k e n, J. C. W i l h o i t, T. L o n g m a n, Dictionary of Biblical Imagery, Downers Grove 1998, s. 359-360.

63 W PnP 5,11 widzimy następujący tekst: ברועכ תורחש מילתלת ויתוצוק גפ םתכ ושאר -Glowa jego - najczystsze złoto, kędziory jego włosów jak gałązki palm, czarne jak kruk” (tłumaczenie Biblii Tyśiąclecia, o rozumieniu tego trudnego fragmentu zob. D. G a r r e t t, P. R. H o u s e, Song of Songs/Lamentations, WBC 23B, Dallas 2004, s. 219. Także włosy się wspomina w opowiadaniach o Ezawie, Samsonie i Eliaszu, ale te konteksty, jak się wydaje, są neutralne pod względem estetyki; zob. A. B e r I i n, Hair, s. 367, tak samo jak białe wlosy w opisie Pana w Dn 7,9 są tylko oznaką natury boskiej (por. Ap 1,14); por. także opis długowłosych woźniców rydwanu Salomona pojawiające się u Flawiusza (Ant., VIII, 7.3).

${ }^{64}$ Ten werset należy uważać za bardziej prawdopodobne źródło, niż Pieśn nad Pieśniami, ponieważ pieśń należy do innej tradycji literackiej (liryka miłosna) i nie ma odpowiedników wśród utworów biblijnych: D. G a r r e t t, P. R. H o u s e, Song of Songs/Lamentations, s. 13-14; por. także M. S. S m i t h, How to Write a Poem, s. 197.

65 Tamże.

חבז־ילע יתירב יתרכ ידיסח (,moi umiłowani, którzy zawarli ze mną przymierze przez ofiarę”)

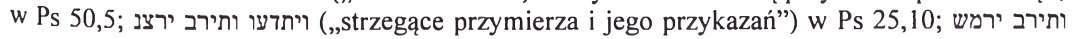


ko niezbyt podobne do תירב ינב, tak samo, jak wyraz תירבה ץרא ינב Najbardziej podobne do qumrańskiego wyrazu pod wzlędem składni są wyrazy מהרבא־תירב ילעב (dosłownie ,właściciele przymierza Abrahama - Rdz 14,13) i דתירב ישנא (dosłownie ,ludzie twojego przymierza" - Ab 1,7 ${ }^{68}$ użyte do oznaczenia ludzi, którzy zawarli ze sobą przymierze, tj. sojuszników. Natomiast w późniejszym okresie spotykamy mnóstwo podobnych przykładów, zarówno tych, które odzwierciedlają rozwój frazeologii biblijnej, ${ }^{69}$ jak i zupełnie nowych, ${ }^{70}$ w tym kilka razy właśnie wyraz תירב ינב. ${ }^{71}$ Tak więc można z całą

(„strzegące jego przymierza”) w Ps 103,18. Jeszcze mniej podobny do fragmentu qumrańskiego pod względem zarówno semantyki, jak i składni jest wyraz יתירבב טיקיזחמ trzymające się mocno mego przymierza") w Iz 56,4 i 6. Także kilka razy w Starym Testamencie (np. Pwt 7,9 i $2 \mathrm{Krn}$ 6,14) Pana nazwano zachowujący przymierze” (tego terminu używa się także w rękopisach qumrańskich, zob. np. 1QM XIV,8). Jednak ta konstrukcja także nie jest podobna składniowo do qumrańskiego wyrazu.

67 Ez 30,5.

68 Wszystkie trzy leksemy (שיא (בעב i) w tym przypadku pełnią tę samą atrybutywną funkcje, zob. o tym A. E. C o w l e y (red.), Gesenius ' Hebrew Grammar as Edited and Enlarged by the Late E. Kautzsch (Second English Edition), Oxford 1910, s. 417; P. J o ü o n, A Grammar of Biblical Hebrew, Subsidia biblica 14/1-2, Roma 2003, s. 469.

תירב ילעב (tym razem już w znaczeniu religijnym) - CD III,4; תירב יש(ו) תא (także w znaczeniu religijnym) - IQS V,9, VI,19; 1Qsa I,2; 1QH 4,8; 1Q36 7,2 (w tym przypadku kontekst został, niestety, utracony, ale ogólna treść utworu także świadczy na rzecz w/w znaczenia); 4Q511 63-64ii5, 63iii5. Także należy wspomnieć tu wyraz $\pi \tilde{a} \varsigma$ i $\sigma \tau \tilde{\omega} v \delta\llcorner\alpha \theta \dot{\kappa} \kappa \eta v$ (,każdy obstawający za przymierzem”) w 1 Mch 2:27 (por. תירבב םעה־לכ דמעיו (dosłownie „i stanął cały naród

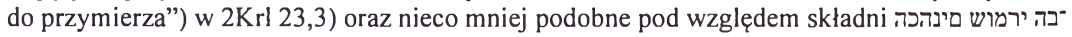
תיר (,kapłani przestrzegające przymierza”) - 1QS V,2, 9 i mocno trzymające się przymierza" - lQS V,3 (por. Iz 56,4 i 6).

70 Przede wszystkim wśród takich wyrazów należy wymienić często spotykany w zwojach znad Morza Martwego wyraz zawierający imiesłów czasownika אוב (,wchodzić”) w koniugacji Qal i rzeczownik תירב: CD II,2, III,10, VI,19, VIII,1, XIII,4, XIX,13-14, XX,25; 1QS II,12, 18; 1QHa XIII,23; 4Q269 2,5; 4Q270 6iiil7 i PAM 43.698 27,1; por. także podobne ליאב לוכ ותירבב (,wszyscy, którzy weszli do jego przymierza”) w 4Q266 3iii24. Także używa się wyra-

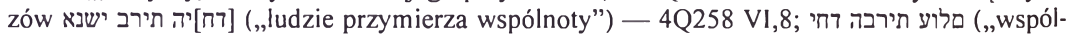

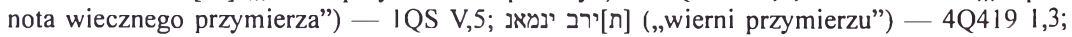
טע מירב [י] מיקמ תירב ישודק (,święty naród przymierza”) nieco mniej podobne pod względem zarówno seman-

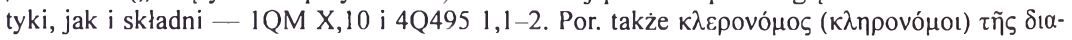
Өńkn („,dziedzic /dziedzice/ przymierza”) w List Barnaby 6,19 i 13,6.

71 Właśnie taki wyraz $w$ interesującym nas znaczeniu spotykamy w szeregu tekstów. Po pierwsze, jak wskazał na to И. ІШ. Ш и ф м а н, Псалом 15I, s. 150, są to Mdr 17,15 (oi vioi $\tau \tilde{\eta} \varsigma \delta ı \theta \eta \dot{\kappa} \eta \varsigma), ~ l Q M ~ X V I I, 8$ i Miszna (Bawa Kamma $1^{\mathrm{b}}$ i $1^{\mathrm{c}}$ ). Po drugie, należy odnotować, że spotykamy wyraz תירב ינב w jeszcze kilku tekstach z Qumran 4Q284 4,2; 4Q501 2, 7 (tu tekst zostal poprawiony przez skrybę:תיר בב ינ\{מ, ale wydaje się, że oba warianty pasują do kontekstu) i 4Q503 7-9,3, Tosefcie (Bawa Kamma 1ª) i Talmudzie Babilońskim (Bawa Mecyja 71 (5 razy), Gittin $23^{\mathrm{b}}$ (2 razy) i Kidduszin $41^{\mathrm{b}}$ ( 2 razy), wszystkie konteksty są podobne do siebie. 
pewnością powiedzieć, że w tym przypadku autor używa dość późnego pozabiblijnego wyrazu.

Podsumowywując wszystko, co zostało powiedziane wyżej, należy odnotować, że wśród przedstawionych przez M. S. Smitha wyróżniających cech tekstu qumrańskiego cztery rzeczywiście można odnieść do języka, ${ }^{72}$ jeszcze trzy cytują fragmenty Biblii nie związane $z$ historią namaszczenia Dawida w Pierwszej Księdze Królewskiej, ${ }^{73}$ wyraz może zawierać aluzję do historii Absaloma. Trudno ocenić uźycie czasownika לשמ; prawdopodobnie nie można uważać go za unikalne. W znacznej mierze późniejszy charakter tej części psalmu, której brak w przekładzie greckim, się potwierdza, ale wydaje się ważniejsze, by rozpatrzyć logikę utworzenia tekstu qumrańskiego.

\section{Inne możliwe świadectwa późniejszego języka}

D. Amara twierdzi, że użycie czasownika ${ }^{74} \mathrm{~W}$ znaczeniu „przekazywać świadectwo o czymś” rzadko się spotyka w języku biblijnym. Pisze, że w języku Talmudu ten czasownik zamienia הנע w kontekście prawnym i używa się z przyimkami ל ב „Świadczyć na rzecz kogoś” i „świadczyć przeciwko komuś”. ${ }^{75}$ Wydaje się, że w tym przypadku należy zwrócić uwagę właśnie na rekcję czasownika. W naszym tekście czasownika użyto w przyimkiem ל; w języku zaś biblijnym w interesującym nas znaczeniu widzimy dwie opcje: albo (zwykle) przyimek $2,{ }^{76}$ albo dopełnienie bliższe. ${ }^{77}$ Ana-

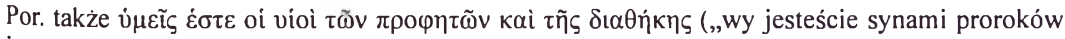
i przymierza") w Dz 3,25.

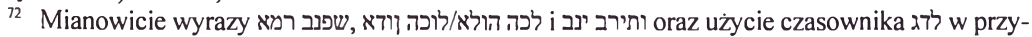

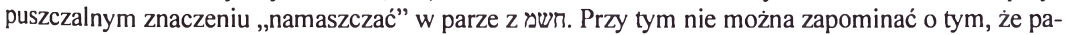
ralelizm terminów לוכה וודא i לכה הולא można porównać i z biblijnym paralelizmem w Ps 114,7.

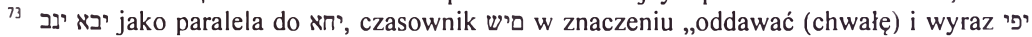

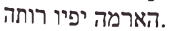

747 דוע koniugacji Hiph'îl - „świadczyć”, „ostrzegać” lub „powoływać kogoś na świadka”.

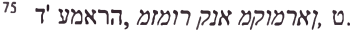

76 W znaczeniu „ogłaszać”, „ostrzegać”, „informować”, „świadczyć”: Rdz 43,3; Wj 19,21,

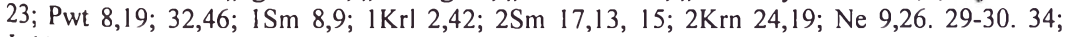
Jr 11,7; 42,19; Am 3,13; Za 3,6. W Ne 13,21; Ps 50,7 i 81,9 w znaczeniu ,świadczyć przeciwko komuś”, ,potępiać kogoś”.

77 W znaczeniu „świadczyć przeciwko komuś” w IKrl 21,10. 13. W Hi 29,11 czasownika użyto w znaczeniu bliskim do pojawiającego się w naszym tekście — „świadczyć na rzecz kogoś” (|| רשא w koniugacji Pi“ēl — „nazywać szczęśliwym”, ,wychwalać”) — wlaśnie z dopełnieniem bliższym. Dość trudny w planie znaczenia jest werset Lm 2,13;zob. D. G a r r e t t, P. R. H o u s e, Song of Songs/Lamentations, s. 371, 387. Zostawiamy bez uwagi te przypadki, 
liza rękopisów znad Morza Martwego także pokazuje niezwykłość takiego użycia: czasownika דיעה w zwojach poza stosowaniem podobnym do biblijnego, ${ }^{78} \mathrm{z}$ reguły używa się z przyimkiem לע. ${ }^{79} \mathrm{~W}$ języku Miszny wskazane przez Amara znaczenie prawdopodobnie także jeszcze się nie do końca rożwinęło i jest charakterystyczne właśnie dla późnego języka Talmudu. ${ }^{80}$

Aיפיה םתמוקב םיהבגה A. Hurvitz wskazuje na niezwykłość konstrukcji םרעשב (,wysokiego wzrostu, o pięknych włosach”). Badacz zwraca uwagę na użycie tu przyimka ב zamiast konstrukcji biblijnej — izafetu. A. Hurvitz mówi o tym, że późniejszy język dąży do „zrzucenia «kajdanów» takich izafetów" (הלא תוכימס-"ילבכ"מ ללחתשה) i przytacza jako dowód kilka fragmentów ze Starego Testamentu i literatury rabinistycznej. ${ }^{81}$ Rzeczywiście w Starym Testamencie nie widzimy przykładów użycia przymiotników הפי (,więkny”) הבג (,wysoki”) z przymiotnikiem ב, tylko izafety. ${ }^{82}$ Już w hebrajskim qumrańskim można

w których czasownik oznacza „powoływać kogoś na świadka (przeciwko komuś)” i używa się do z dopełnieniem bliższym (i czasami dodatkowo z przyimkiem ב): Pwt 4,26; 30,19;31,28; Iz 8,$2 ; \mathrm{Jr} 32,10 ; 25,44$. W Iz 8,2 widzimy użycie czasownika z przyimkiem ל, ale w absolutnie innym znaczeniu: „powoływać sobie na świadka”. Także w Ml 2,14 czasownika użyto z podwójnym przyimkiem ון ויבו .... w znaczeniu „być świadkiem między kimś a kimś”. W Ne 13,15 i Jr 6,10 czasownika użyto bez rekcji (w ostatnim przypadku można uważać przyimek לעיב za rekcję czasownika, ale ten przyimek lepiej odnieść raczej tylko do poprzedniego czasownika רבד „mówić”; por. F. B r o w n, S. R. D r i v e r, C. A. B r i g g s, The Hebrew and English Lexicon, s. 730 .

78 W znaczeniu „ostrzegać" z dopełnieniem bliższym w 4Q266 13,4. Dwa razy spotykamy użycie czasownika z przyimkiem $\mathrm{Z}$ i jedno z tych użyć jest bardzo bliskie pod względem znaczenia do tekstu psalmu. W 4Q390 1,4 czasownika użyto w znaczeniu „ostrzegać”, w 4Q443 2,7 zas (ale w koniugacji Qal) w znaczeniu „świadczyć na rzecz kogoś”: וידעו יל ביר - „rozsądzi na moją korzyść i objawienia go będą świadczyć dla mnie”.

79 W prawdopodobnie neutralnym znaczeniu ,świadczyć o czymś” w CD IX,20 i w znaczeniu ,świadczyć przeciwko komuś” w CD XIX,30; 1Qsa I,11 i 4Q227 2,3. W 4Q377 li7 stan rękopisu, niestety, nie pozwala na ustalenie ani ścisłego znaczenia, ani rekcji czasownika.

ושל רצוא ,יקסבוסוק י 'ח ח זטשת םילשורי, הנשמה my w tekście psalmu: w Jewamot $7^{\mathrm{c}}$ widzimy znaczenie „poświadczyć/poinformować kogoś o czymś”; w Jewamot $16^{\top}$ czasownika użyto z konstrukcją רואל - „świadczyć przy świetle (kagańca i księżyca)". Użyte w Bawa Kamma $4^{\text {d }}$ ma, jak się wydaje, odcień zwrotności („świadczą dla siebie/w swoim interesie”) i z reguly pomija się to słowo w przekładach, por. J. N e u s n e r, The Mishnah: A New Translation, New Haven 1988, s. 511.

81 ונושל,

82 W większości przypadków te przymiotniki są odosobnione albo używa się ich w znaczeniu stopnia wyższego z przyimkiem הבג : הבו w Rdz 7,19; Pwt 3,5, 28,52; 1 Sm 2,3 (2 razy); 9,2; $1 \mathrm{Krl} 17,23 ; 2 \mathrm{Krl} \mathrm{17,10;} \mathrm{Hi} \mathrm{41,26;} \mathrm{Ps} \mathrm{104,18;} \mathrm{138,6;} \mathrm{Koh} \mathrm{5,7} \mathrm{(3} \mathrm{razy);} \mathrm{12,5;} \mathrm{Iz} \mathrm{2,} \mathrm{15;} \mathrm{5,} \mathrm{15;} \mathrm{10,33;}$ 30,$25 ; 40,9 ; 57,7 ;$ Jr 2,20; 3,6; 17,2; 51,58; Ez 1,18; 17,22; 24, 21.31; 40,2; Dn 8,3 (3 razy); So 1,16; listę odosobnionych użyć przymiotnika הפג zob. wyżej. Trzy razy przymiotnika 
zauważyć tendencję do zmiany sytuacji językowej: wśród siedmiu użyć (poza naszym tekstem) przymiotnika המוקב הובג spotykamy (dosłownie ,wysoki wysokością”) w 1QH ${ }^{\mathrm{a}}$ XXVII,3. ${ }^{83}$ Tak więc można odnieść wymienione frazy do przykładów użycia języka pobiblijnego.

Jako jeszcze jeden przykład możliwego użycia wyrazy pobiblijnego Hurvitz przytacza rzeczownik דיגנ (,przywódca”) z przyimkiem ל w 11Q5 XXVIII 11. Badacz jednak sam uznaje niepewność tego twierdzenia. Odnotowuje, że w Starym Testamencie w kontekście namaszczenia na króla używa się tylko wyrazu לע דיגנ. W tym samym czasie w Księgach Kronik wyrazu ליגנ ל ל ל trzy razy użyto w stosunku do rozmaitych dostojników. Według Hurvitza, nie można jednak twierdzić, że w Starym Testamencie istniał jakikolwiek podział zgodnie ze statusem władcy, ponieważ w stosunku do dostojników także używa się לע דיגנ Ręopisy znad Morza Martwego i Miszna nie przedstawiają nam dodatkowych świadectw. ${ }^{85} \mathrm{~W}$ tym przypadku musimy zgodzić się z Hurwitzem i przyznać, że ליגנ można uważać tylko za pojawiającą się w psalmie cechę późnego hebrajskiego biblijnego. ${ }^{86}$

użyto $\mathrm{z}$ apozycją oznaczającą dokładną wysokość: Est 5,14; 7,9; Ez 41,22. We wszystkich pozostałych przypadkach przymiotników użyto w izafecie: הבג w przenośnym znaczeniu (,wyniosły”) ze słowami (יניע (,oczy”), בל (,serce”), הור („duch”) w Ps 101,5; Prz 16,5; Koh 7,8 i w dosłownym znaczeniu ze słowem המוק (,wysokość”), jak w naszym psalmie, w Ez 31,3 (por. także werset $1 \mathrm{Sm} \mathrm{16,7} \mathrm{z} \mathrm{historii} \mathrm{namaszczenia} \mathrm{Dawida,} \mathrm{gdzie} \mathrm{przymiotnik} \mathrm{substantywizowany}$ pojawia się w izafecie ze słowem המוק); o użyciu הפי z rozmaitymi rzeczownikami zob. wyżej.

${ }^{83}$ Oprócz wymienionego przypadku w 4Q225 2 il12 i 4Q372 1,12 przymiotniki są odosobnione, w 4Q391 65,7 z apozycją, w 4Q481 c 3 i PAM $4368213 i 2$ stan tekstu nie pozwala na ustalenie kontekstu. W 4Q436 lii3 widzimy izafet, którego pierwszym członem jest prawdopodobnie przymiotnik substantywizowany (ten wniosek opiera się na rekonstrukcji tekstu z użyciem rękopisu 4Q435, zob. F. G. M a r t í n e z, E. J. C. T i g c h e l a a r (red.), The Dead Sea Scrolls Study Edition, Leiden 1999, s. 916-917. Takich przykładów ze słowem הפי w rękopisach qumrańskich niestety brak: oprócz tekstu Psalmu 151 przymiotnik jest odosobniony (4Q180 2-4ii2) lub jest częścią izafetu (4Q418 167a+b,5; 11Q19 LXIII,11).

84 נושל, 'איברוה 'אי

${ }^{85}$ Z wyjątkiem tekstu psalmu słowa דיגנ użyto w zwojach znad Morza Martwego tylko jeden raz: w 4Q504 1-2iv7 z przyimkiem לע (תויהל) (aby (Dawid) był)

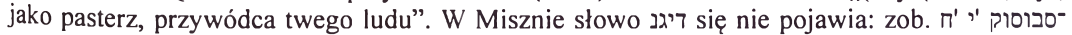
וושל רצוא ,יקוק.

${ }^{86}$ Jeśli rozszerzyć strefę znaczenia, w tekście biblijnym słowa דיגנ we wszystkich znaczeniach i konstrukcjach składniowych używa się w większości wypadków z przyimkiem לע: ISm 9,16;10,1;13,14;25,30;2Sm 5,2; 6,21; 7,8; $1 \mathrm{Krl} \mathrm{1,35;14,7;16,2;} \mathrm{Krl} 20,5 ; 1 \mathrm{Krn} \mathrm{9,20;}$ 11,$2 ; 17,7 ; 26,24 ; 2 \mathrm{Krn} 6,5 ; 31,12$; w kilku przypadkach (zwłaszcza w późnym języku) widzimy także izafet: $1 \mathrm{Krn} 9,11 ; 2 \mathrm{Krn} \mathrm{28,7;31,13;35,8;} \mathrm{Ne} \mathrm{11,11;} \mathrm{Ez} \mathrm{28,2;} \mathrm{Dn} \mathrm{11,22.} \mathrm{Trzy} \mathrm{razy}$ rzeczownika użyto $\mathrm{z}$ przyimkiem ב: $2 \mathrm{Krn} 11,11$. 22; Jr 20,1. W wielu przypadkach słowo jest odosobnione: $1 \mathrm{Krn} 5,2 ; 13,1 ; 27,4 ; 28,4 ; 29,22 ; 2 \mathrm{Krn} 32,21$; Hi 29,10;31,37; Ps 76,13; 


\section{Porównanie tekstu w 11Q5 z Vorlage Septuaginty}

Wyżej już rozpatrzyliśmy niektóre cechy Psalmu 151. Podczas analizy wyjaśniliśmy, że niektóre z nich mają odpowiedniki w hebrajskim biblijnym, niektóre należą do późniejszego stadium rozwoju języka hebrajskiego i pojawiają się w rękopisach znad Morza Martwego, trzecie zaś są unikalne dla języka swojej epoki i jej następnych. W świetle tych faktów koniecznie należy rozpatrzyć hebrajski tekst psalmu w całości i spróbować odnaleźć w nim ślady strategii, którą autor posługiwał się przy tworzeniu utworu. Sytuacja naszym zdaniem wygląda następująco:

יחא ןמ יתייה וטק

(Septuaginta: יחאב יתייה ןטק) Nie znaleźliśmy dokładnego odpowiednika tej frazy w Starym Testamencie. ${ }^{87} \mathrm{O}$ Dawidzie mówi się jak o „najmłodszym” (ן) w 1Sm 16,11 i 17,14. Wydaje się, że autor zbudował tę frazę używając materiału prawdopodobnie $\mathrm{z}$ pierwszego $\mathrm{z}$ w/w wersetów (bardziej podobny kontekst). ${ }^{88}$

יבא ינבמ ריעצו

(Septuaginta: יבא תיבב ריעצו) Wariant z pewnym prawdopodobieństwem zachowany w przekładzie greckim przypomina cytat z Sdz 6,15. ${ }^{89}$ Tekst 11Q5 znów przypomina przeróbkę idei pojawiającej się w 16. rozdziale Pierwszej Księgi Samuela. Wobec Dawida w tekście biblijnym słowa ריעצ się nie używa. ${ }^{90}$ Paralelizm między יחא i przypomina Rdz 49,8.

\footnotetext{
Prz 28,16; Iz 55,4; Dn 9,25-26. Z przyimkiem ל słowa używa się tylko w Księgach Kronik (1Krn 12,28; 27,16 i 2Krn 19,11), których język można nazwać klasycznym przykladem późnego hebrajskiego biblijnego; zob. opis w R. P o I z i n, Late Biblical Hebrew: Toward an Historical Typology of Biblical Hebrew Prose, HSM 12, Missoula 1976, s. 27-84. Należy jednak odnotować, że ten wyraz wydaje się nieco niezwykły, ponieważ w Księgach Kronik nie używa się tego słowa z przyimkiem ל w interesującej nas konstrukcji składniowej, w której występuje w roli dopełnienia bliższego: „ustanawiać kogoś przywódcą kogoś”, wszystkie przypadki opisują fakt, który już się wydarzył.

87 Zob. listę użyć słowa ("mały") w A. E v e n $\mathrm{S}$ h o s h a n, A New Concordance of the Old Testament: Thesaurus of the Language of the Bible Hebrew and Aramaic Roots. Words. Proper Names, Phrases and Synonyms, Jerusalem 1993, s. 1014-1015.

88 ,Rzekł (Jesse): „Pozostał jeszcze najmniejszy”.

89 - _, ,a ja (Gedeon) jestem najmłodszy w domu mego ojca”.

90 Zob. A. Even S h o s h a n, A New Concordance, s. 990.
} 
ונוצל העור ינמישיו

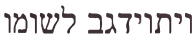

בגוע ושע ידי - - - - - - ב

רונכ יתועבצאו
(Septuaginta: ונאצ תא יתיער) Oba warianty frazy wyglądają na przekształconą wersję $1 \mathrm{Sm} \mathrm{16,11.91}$

(brak w Septuagincie) Jak już powiedziano, nie ma prawdopodobnie nic sprzecznego $\mathrm{z}$ językiem biblijnym $\mathrm{w}$ tym, że czasownik ma przy sobie rzeczownik oznaczający zwierzęta. Sama konstrukcja לשמ מיש (,ustanawiać władcą") w znacznej mierze przypomina Rdz 45,892. Słowo הידג prawdopodobnie wzięto z PnP $1,8 .{ }^{93}$

(Septuaginta: בגוע ושע ידי) W tekście biblijnym brak dokładnego odpowiednika tej frazy. ${ }^{94}$ Ten wiersz i następny są autorskim wyrażeniem wyobrażenia o Dawidzie jak o twórcy szeregu instrumentów muzycznych $^{95}$

(רונכ וננכ יתעבצא Znów brak odpowiednika tej frazy $\mathrm{w}$ tekście biblijnym. ${ }^{96}$ W tym samym czasie do stworzenia paralelizmu między tym wierszem i poprzednim używa się standardowych biblijnych par $^{97}$

91 - „ואצב הער הנהו - on pasie owce”.

92 Ten kontekst odnosi się do historii Józefa: (Bóg) usta-

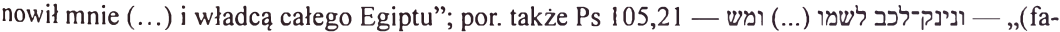
raon) ustanowil go (Józefa) (...) i władcą całego swojego majątku".

93 Jest to jedyne użycie tego „odpowiednika” ידג w Starym Testamencie: A. E v e n - S h o sh a n, A New Concordance, s. 225. W zwojach znad Morza Martwego to słowo pojawia się tylko w naszym psalmie: M. G. A b e g g i in., The Dead Sea Scrolls Concordance, s. 173. Jako dodatkowe świadectwo na rzecz zależności w/w wersetu od tekstu Pieśni nad Pieśniami można przytoczyć jeszcze jeden ważny dowód. Właśnie w PnP 1,8 widzimy w parze slowa הידג i ואצ jak w naszym psalmie, podczas gdy standardową biblijną parą dla słowa ואצ jest, jak się wydaje, ע7ר (,stado”): Ps 78,52. 70--71 (część tradycji związanej z Dawidem); Prz 27,23; Ez 34,12; Mi 2,12 (należy odnotować, że w tym przypadku chodzi nam właśnie o paralelizm, ponieważ przy wymienianiu i oznaczeniu całości za pomocą skrajnych punktów ze słowem ואצ zwykle używa się rzeczownika רקב (,bydło").

94 Zob. np. użycia słowa בגוע w A. E v e n S h o s h a n, A New Concordance, s. 837.

95 Por. np. 2Krn 7,6.

96 Zob. np. użycia słowa רונכ w A. E v e n S h o s h a n, A New Concordance, s. 550.

97 Paralelizm między 7 (,ręka”) i עבצא (,palec”) widzimy m. in. w Ps 144,1 (tradycja związana z Dawidem); PnP 5,5; Iz 2,8 i 17,8. בגוע używa się w parze z רונכ w Hi 21,12, 30,31 i Ps 150,4. השע Jeśli nasza rekonstrukcja Vorlage Septuaginty jest słuszna, paralelizm między czasownikami („,robić”) i ווכ („tworzyć”, w koniugacji Pōlēl) można spotkać np. w Ps 99,4, 119,73; Iz 45, 18. 
דובכ הוהיל המישאו

ישפנב ינא יתרמא

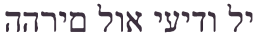

ילע ודיגי אול תועבגהו (brak w Septuagincie) Jak już powiedziano, דובכ מיש (,oddawać chwałę) zgadza się z językiem biblijnym. Taka konstrukcja pojawia się w Joz 7,19 i Iz 42,12, ale nie znaleźliśmy dokładnego jej odpowiednika w Starym Testamencie.

(brak w Septuagincie) Znów nie znaleźliśmy odpowiednika tej frazy w Starym Testamencie. Wyraz שפנב רמא (,mówić w [głębi] duszy") pojawia sie, jak powiedziano wyżej, w okresie pobiblijnym prawdopodobnie pod wpływem języka aramejskiego. W tym samym czasie, razem z Hurvitzem ${ }^{98}$ należy odnotować późną składnię wyrazu. Wydaje się, że ta fraza przedstawia znaczną składniowa (i semantyczną) zależność od języka Księgi Koheleta, w której kilka razy spotykamy nadzwyczaj podobne wyrazy ${ }^{99}$

(brak w Septuagincie) W tym wyrazie pojawia się składniowa konstrukcja ל דיעה charakterystyczna dla późnego języka.

(brak w Septuagincie) Wyraz לע דיגה w neutralnym znaczeniu pojawia się, jak już powiedziano, dopiero w zwojach znad Morza Martwego. Paralelizm między דיעה („świadczyć”, ,informować”) i דיגה (,informować”, „opowiadać”) nieco przypomina $1 \mathrm{Sm} 8,9,{ }^{100}$ ale nie można $\mathrm{z}$ pewnością twierdzić o wpływie tego tekstu na psalm.

98 ונושל, ינא יתלטק (,zrobilem ja”) z whaśnie taką kolejnością słów (osobowa forma czasownika poprzedzjąca zaimek osobowy) jest charakterystyczną cechą późnych ksiąg Starego Testamentu.

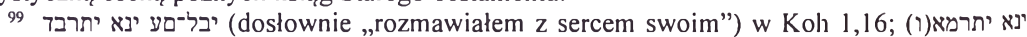
יבלב (,powiedziałem w sercu swoim”) w Koh 2,1, 15, 3,17-18; ינא יתרמאו (,powiałem ja”) w Koh 9,16; יבלב יתרבדו („mówiłem w sercu swoim”) w Koh 2,15. Także ta konstrukcja składniowa jest ogólnie nadzwyczaj wyraźną cechą Księgi Koheleta; obliczenia liczby jej użyć w porównaniu z pozostałymi księgami Starego Testamentu i inne ważne uwagi zob. w R. H o 1 m s t e d t, יבְלו: The Syntactic Encoding of the Collaborative Nature of Qohelet's Experiment, JHS 9/2009; www.jhsonline.org/Articles/article 121.pdf (dostęp: 22 X 2014).

100 Pan mówi Samuelowi: דלמה טפשמ מהל תדגהו םהב דיעת דעהיכ-,tylko wyraźnie ich ostrzeż i oznajmij im prawo króla". 
ירבד תא םיצעה

ישעמ תא ואוצהו

רבדי ימו דיגי ימ יכ ישעמ תא רפסי ימו ימוי ימוי

האר לוכה וודא

לוכה הולא

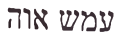

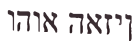

(brak w Septuagincie) Wydaje się, że nie ma w tej frazie nic "niebiblijnego".

(brak w Septuagincie) Ten wyraz także nie jest sprzeczny z językiem Starego Testamentu. Paralelizm między czterema słowami מירה (,góry”), תועבג (,wzgórza”), םיצע (,drzewa”) i ואצ (,trzoda") w tym kontekście najbardziej przypomina, jak się wydaje, wymienienie chwalących Pana w Ps 148,8-10, gdzie pierwsze trzy z wymienionych członów znajdują się w tej samej kolejności przeplatając się z innymi rzeczownikami, zamiast czwartego zaś pojawiają się היח (,[dzikie] zwierzęta”), המהב (,bydło"), שמר (,gady”) i רנכ רופצ (,skrzydlate ptactwo").

(Septuaginta: ינדאל דיגי ימו) Oba warianty tego wyrazu zgadzają się z językiem biblijnym. Wydaje się, że potrójnego paralelizmu między ריגה (,,informować”), רבד (,opowiadać”) i רפס (,opisywać”) w tekście Starego Testamentu brak. Przy tym ta fraza nieco wygląda na przeróbkę Ps 40,6. ${ }^{101}$

(Septuaginta: עמש אוה / הוהי אוה) W tekście qumrańskim widzimy przypuszczalne użycie pozabiblijnych wyrazów לוכה וודא i לוכא לוכה. W tym samym czasie paralelizm między וודא i może odsyłać do Ps 114,7.102 Czasowniki עמש (,,słyszeć”) i ויזאה i,przysłuchiwać się") użyte w paralelnych konstrukcjach są standardową parą biblijną ${ }^{103}$

101 , - , רפסמ ומצע הרבדאו הדיגא ךילא ךרע ןיא ונילא ךיתבשחמו ךיתאלפנ יהלא הוהי התא תישע תובר , , wiele ty uczyniłeś swych cudów, Panie, Boże mój, a w zamiarach Twoich wobec nas nikt "ci nie dorówna. I gdybym chciał je wyrazić i opowiedzieć, będzie ich więcej niżby można zliczyć". W tym przypadku czasownika רפס użyto w znaczeniu „liczyć” i nie ma paralelizmu między nim i pierwszymi dwoma, ale nie można zupelnie wykluczać możliwości wpływu tego tekstu na psalm.

102 Zadrżyj, ziemio, przed obliczem Pana calej ziemi, przed obliczem Boga Jakubowego".

103 Rdz 4,23; Wj 15,26; Lb 23,18; Pwt 1,45; 32,1; Sdz 5,3; Hi 33,1; 34,2; 16; Ps 17,1; 39,13; 49,$2 ; 54,4 ; 84,9 ; 143,1$; Iz 1,2. 10; 28,23; 32,9; 42,23; 64,3; Jr 13,15; Oz 5,1; Jl 1,2. 
ינחשומל ואיבנ חלש

ינלדגל לאומש תא

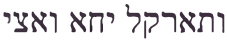

הארמה יפיו רותה יפיפי יחואי

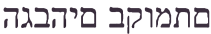

םרעשב םיפיה מיהגר
Pojawiająca się w przypuszczalnym Vorlage Septuaginty fraza הוהי אוה (,[właśnie] on jest Panem") może być zapożyczona z fragmentu pieśni Dawida w 1 Krn 16,14. ${ }^{104}$ (Septuaginta: וכאלמ חלש אוה) Tekst grecki prawdopodobnie $\mathrm{w}$ trochę mniejszym stopniu bezpośrednio zależy od tekstu Starego Testamentu, gdzie Samuela dwa razy nazwano prorokiem (איבנ) ${ }^{105}$ oraz wspomniano jako przywódcę grupy prorokujących. ${ }^{106}$ Słowa דאלמ (,posłaniec”) w Starym Testamencie wobec Samuela się nie używa. ${ }^{107}$ To użycie należy nazwać raczej skutkiem literackiej obróbki idei przedstawionej w historii namaszczenia Dawida.

(brak w Septuagincie) Wydaje się, że czasownika לדג użyto tu w późnem pozabiblijnym znaczeniu „namaszczać”, które się rozwinęło pod wpływem języka aramejskiego. (Septuaginta: מילדגו םיפי יחא) Już podkreślaliśmy późny charakter użycia w tekście qumrańskim przymiotników z przyimkiem ב zamiast izafetu charakterystycznego języka Starego Testamentu. ${ }^{108}$ Wydaje się, że wyraz הארמה יפיו רותה יפי (,urodziwi i przystojni”)

104 (Właśnie) on, Pan, jest naszym Bogiem, jego wyroki obejmują świat cały". Za alternatywne źródło można uważać także Ps 105,7, gdzie pojawia się absolutnie ta sama fraza.

${ }^{105} 1 \mathrm{Sm} 3,20 ; 2 \mathrm{Krn} 35,18$; zob. A. E v e n $\mathrm{S}$ h o s h a n, A New Concordance, s. 733-734. Jednak żaden $\mathrm{z}$ tych kontekstów nie jest związany $\mathrm{z}$ historią namaszczenia Dawida. W Qumran słowa איבנ wobec Samuela używa się tylko w naszym psalmie i w tytule psalmu 15IB (11Q5 XVIII 13); zob. M. G. A b e g g i in., The Dead Sea Scrolls Concordance, s. 502.

106 ISm 19,20 i dalej.

107 Zob. A. E v e n S h o s h a n, A New Concordance, s. 658-659. W Qumran wobec Samuela słowa ראלמ także się nie używa; M. G. A b e g g i in., The Dead Sea Scrolls Concordance, s. 447-448. Do Dawida w tekście Starego Testamentu kilkakrotnie kieruje się posłańców (מיכאלמ: ISm 16,19, 19,11-21), ale we wszystkich tych przypadkach posyła ich nie Pan, lecz Saul.

${ }_{108}$ Przypomnijmy, że paralelę do użycia w psalmie przymiotnika הבג (,wysoki”) znajdujemy w IQHa, odpowiednich zaś konstrukcji z הפי (,piękny”) brak zarówno w Starym Testamencie, jak i nawet jeszcze wśród utworów qumrańskich. Oba przymiotniki pojawiają się w jednej konstrukcji w Ez 31,3, ale zależność naszego tekstu od Księgi Ezechiela jest mało prawdopodobna w świetle tego, że oba słowa pojawiają się i w historii namaszczenia Dawida, o tym zob. dalej. 
הוהי רחב אול

םב םיהולא

ואוצה רחאמ ינחקיו חלשיו

שדוקה ןמשב ינחשמיו odsyła do Rdz 39,6 lub z mniejszym prawdopodobieństwem do Rdz 29,14. W tym samym czasie pod względem treści obie wersje są przykładami swobodnego traktowania idei zawartych w historii namaszczenia Dawida, gdzie podkreśla się piękno samego przyszłego króla (1Sm 16,12) i wysokość jego brata Eliaba (1Sm 16,7). Motyw pięknych włosów braci Dawida mogł zostać zapożyczony z historii Absaloma (2Sm 14,25) lub z mniejszym prawdopodobieństwem z PnP 5,11. Pojawiająca się w tekście qumrańskim idea wyjścia braci naprzeciw Samuelowi może pochodzić z opowiadania o starszyźnie Betlejem w 1Sm 16,4. Qumrańskie הבג jest bliższe do historii namaszczenia Dawida, niż przypuszczalne לודג w Vorlage Septuaginty. ${ }^{109}$ (Septuaginta: הוהי םב הצר אולו) Jeśli nasza rekonstrukcja Vorlage Septuaginty jest słuszna, należy uważać tekst qumrański za bardziej bliski do historii opowiedzianej w Pierwszej Księdze Samuela, gdzie do opisania odmówienia braciom Dawida wybrania używa się czasownika רחב. ${ }^{110}$ Czasownika הצר (,sprzyjać”) z przyimkiem ב używa się wobec samego Dawida w innym fragmencie związanej $\mathrm{z}$ nim tradycji w podobnym kontekście (1Krn 28,4). (וןאצה רחאמ ינחקיו Peptuaginta) Pojawiający się w tekście qumrańskim gendiadis przypomina zwrócenie się Samuela do Jessego w 1 Sm 16,11."11

(Septuaginta: ותחשמ ןמשב ינחשמש Wyraz ומשיו (,olej namaszczenia”) spotykamy tyl-

\footnotetext{
${ }^{109}$ Por. $1 \mathrm{Sm} \mathrm{16,7.}$

111) 1 Sm 16,8-10. Także w znaczeniu analogicznym do (,nie wybral”) w 1Sm 16,7 widzimy czasownik סאמ (,odrzucać”).

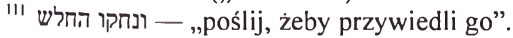


ומעל דיגנ ינמישיו

ko w Pięcioksięgu w wielu kontekstach. ${ }^{112}$ Prawdopodobnie do tych kontekstów powinniśmy odnieść ten przypadek. Wydaje się, że pojawiający się $\mathrm{w}$ tekście qumrańskim wyraz שדוקה ומש („olej święty”) odsyła do Ps $89,21^{113}$

(brak w Septuagincie) Jak już powiedziano, rzeczownik דיגנ (,przywódca”) użyty $\mathrm{z}$ przyimkiem $ל$ może być przykładem użycia w psalmie późnego języka i zawierać odsyłacz do języka Ksiąg Kronik. Nie możemy jednak twierdzić tego bezapelacyjnie.

ותירב ינבב לשומו

(brak w Septuagincie) Ten fragment zawiera תירב ינב (,synowie przymierza”), którego brak w Starym Testamencie i który się rozpowszechnił już w okresie pobiblijnym.

Tak więc, Vorlage Septuaginty jest pod względem krytyki tekstu (leksyki) bezpośrednio związane z opowiadaniem 1Sm 16,1-13 w sześciu przypadkach. ${ }^{114}$ Wydaje się, że jeszcze w trzech przypadkach w tekście użyto materiału należącego do związanej z Dawidem tradycji, ale znajdującego się poza historią namaszczenia Dawida. ${ }^{115}$ W czterech przypadkach Vorlage greckiego tekstu psalmu korzysta prawdopodobnie z innych tekstów Starego Testamentu. ${ }^{116}$

${ }^{112} \mathrm{Wj} 25,6 ; 29,7.21 ; 30,25.31 ; 31,11 ; 35,8.15 .28 ; 37,29 ; 39,38 ; 40,9 ; \mathrm{Kpł} 8,2.10 .12 .30$; 10,$7 ; 21,10.12 ;$ Lb 4,16 .

${ }^{113}$ Ten werset należy uważać za najbardziej prawdopodobne źródło zapożyczenia jako część tradycji związanej z Dawidem. Jednak nie można wykluczać i Lb 35,25, gdzie także użyto tego wyrazu. Por. także שדק־תחשמ ןמשמwiętego namaszczania” lub „święty olej namaszczania) w Wj 30,25, 31 i wariant שדק החשמה ןמשמש w W W 37,29.

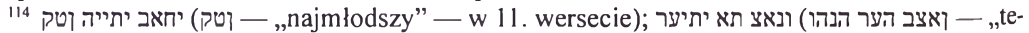

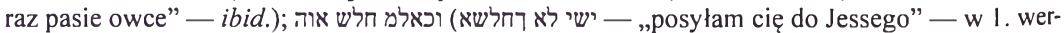

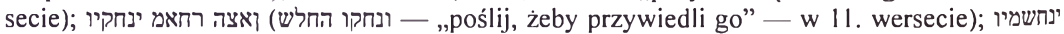
,wziął więc Samuel róg z oliwą i namaścił go" — w 13. wersecie); מיניע הפי־םע) - o pięknych oczach” — o Dawidzie w 12. wersecie).

${ }^{115}$ Do tych przypadków zaliczamy paralelizm między słowami עבצא i עי i (Ps 144,1) oraz z nieco mniejszym prawdopodobieństwem wyraz הוהי אוה (1Krn 28,4). Wyobrażenie o Dawidzie jak o twórcy instrumentów muzycznych nie włączamy do tej grupy, ponieważ wyrażenie tej idei w psalmie nie ma, jak się wydaje, bezpośredniego leksykalno-syntaktycznego związku z odpowiednimi opowiadaniami w innych źródłach.

יבא תיבב ריעצה יכנאו mogło powstać skutkiem nieznacznego zmienienia יבא תיבב ריעצ 116 (,a ja jestem najmłodszy w domu mego ojca”- - Sdz 6,15); החשמה ןמש wydaje się, że odsyła do liczcznych w/w fragmentów Pięcioksiągu, paralelizm między בגוע i רונכ przypomina Hi 21,12, 
Następnie zwróćmy naszą uwagę na hebrajski tekst zachowany w rękopisie 11Q5. W dziewięciu przypadkach ukazuje bezpośredni związek z historią namaszczenia Dawida. ${ }^{117}$ Dodatkowego materiału z tradycji związanej z Dawidem użyto trzy razy. ${ }^{118} \mathrm{~W}$ czternastu przypadkach tekst psalmu odsyła, jak się wydaje, do innych tekstów Starego Testamentu. ${ }^{119}$ Oprócz tego, w dziewięciu przypadkach w tekście psalmu znajdują się wyrazy nietypowe dla gramatyki biblijnej lub biblijnego użycia słów. ${ }^{120}$

Jak widzimy, w tekście qumrańskim wzrasta liczba zapożyczeń z 16 rozdziału Pierwszej Księgi Samuela i niezwiązanych z tradycją Dawidową tekstów Starego Testamentu oraz pojawiają się niespotykane dla języka biblijnego słowa i wyrazy. Wzrost liczby cytatów biblijnych można byłoby rozjaśnić bardziej rozwlekłym tekstem Psalmu 151 z Qumran, ale koniecznie trzeba zwrócić uwagę na pewne regularności zauważone przez nas podczas porównywania dwóch wersji.

Po pierwsze, należy zwrócić uwagę na te fragmenty, w których tekst qumrański i Vorlage Septuaginty przedstawiają dwa różne warianty tej samej frazy. W takich fragmentach da się zauważyć pewną tendencję: tekst psalmu w wersji 11Q5 jest przybliżony do prozaicznego opowiadania o Dawidzie, co należy rozjaśnić, jak się wydaje, harmonizacją tekstu. $^{121} \mathrm{Z}$ powodu tego, że wiele związanych zarówno z psalmem,

30,31 lub Ps 150,4. Ostatni w tej grupie jest paralelizm między czasownikami השע i וכ וכ 99,4, 119,73; Iz 45,18).

- ונוצל יל יל וינבב יתיאר יכ) האר לוכה וודא prawdopodobnie

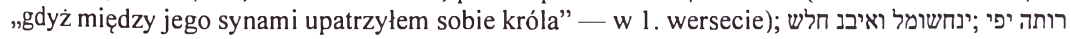

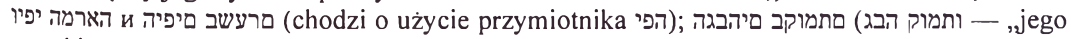

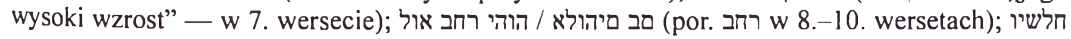
שוקוקה ומשב ינחשמיו ;אוצה רחאמ ינחקיו

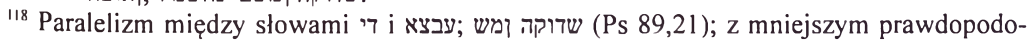
bieństwem do tej grupy także można zaliczyć użycie rzeczownika דיגב z przyimkiem ל pojawiające się w IKrn 12,28 (lista przywódców wojska Dawida), 27,16 (lista urzędników za panowania Dawida).

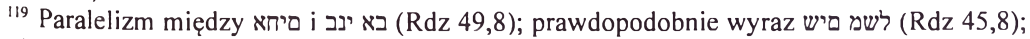
הידג (PnP 1,8); składnia wyrazu שפנב ינא יתרמא (Księga Koheleta); דובכ טיש (prawdopodobnie

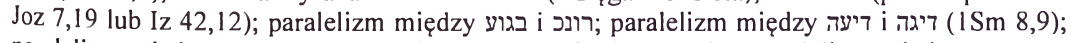

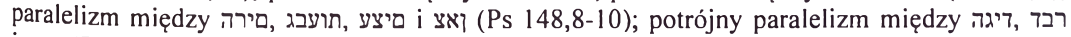

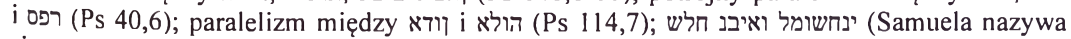

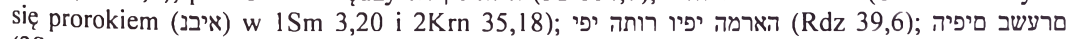
(2Sm 14,25). Wydaje się, że do tej grupy należy także zaliczyć standardową biblijną paralelę

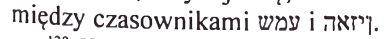

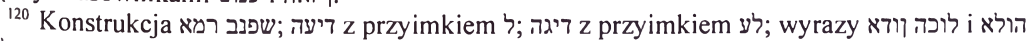

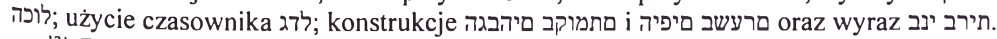

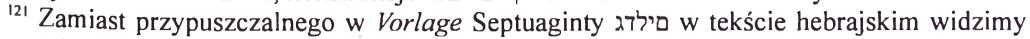
טיהבג pojawiające się w historii namaszczenia. הצר (prawdopodobnie zapożyczony z tradycji 
jak i z całym tekstem rękopisu problemów dopiero czeka na rozwiązanie, jesteśmy zmuszeni zrezygnować z próby jednoznacznego ustalenia przyczyn tej harmonizacji, ${ }^{122}$ ale z punktu widzenia tradycyjnej krytyki tekstu wtórność takiej redakcji nie ulega wątpliwości. ${ }^{123}$

Po drugie, warto zwrócić uwagę także na te fragmenty tekstu qumrańskiego, których brak w Septuagincie. Przy ich analizie okazuje się, że prawie każdy wiersz jest nacechowany albo oczywistym odsyłaczem do pewnego tekstu Starego Testamentu nie związanego z historią namaszczenia, albo użyciem wyrazu niecharakterystycznego dla języka biblijnego, czego nie można powiedzieć ani o przypuszczalnym Vorlage Septuaginty, ani o odpowiadających mu wierszach tekstu qumrańskiego. W tym sensie kontrast między dwoma fragmentami tekstu jest na tyle wyraźny, że prawdopodobieństwo przypadkowego zbiegu okoliczności sprowadza się do minimum: dwie części tekstu demonstrują różne strategie tworzenia tekstu. Możemy to zilustrować za pomocą następującej tablicy:

\begin{tabular}{|c|c|}
\hline Tekst 11Q5 & Vorlage LXX \\
\hline יחא ןמ יתייה ןטק & יחאב יתייה וטק \\
\hline $\begin{array}{l}\text { יבא ינבמ ריעצ - prawdopodobny odsyłacz } \\
\text { do Rdz 49,8 (paralelizm) }\end{array}$ & $\begin{array}{l}\text { możliwy odsyłacz do } \\
\text { Sdz 6,15 } \\
\text { Sdy }\end{array}$ \\
\hline ונוצל העור ינמישיו & ונאצ תא יתיער \\
\hline $\begin{array}{l}\text { ויתוידגב לשומו - prawdopodobny odsyłacz } \\
\text { do Rdz 45,8 i PnP 1,8 (paralelizm) }\end{array}$ & brak \\
\hline בגוע ושע ידי & בגוע ושע ידי \\
\hline רונכ יתועבצאו & רונכ וננכ יתעבצא \\
\hline דובכ הוהיל המישאו & brak \\
\hline
\end{tabular}

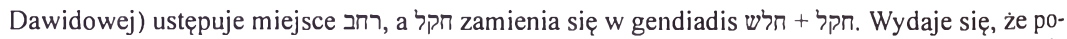
dobną sytuację widzimy jeszcze w dwóch przypadkach: החשמה ומש z Pięcioksiągu zamienia się w שרוקה ומש należący do tradycji Dawidowej, a słowo ראלמ nieuzywane wobec Samuela w Starym Testamencie zamienia się w bardziej zwykły epitet איבנ.

122 Ta kwestia może być nierozerwalnie związana w szczególności z kwestią kanoniczności zbioru 11Q5: jeśli celem redaktora zachowanego w 11Q5 tekstu hebrajskiego było włączenie psalmu do zbioru kanonicznego, takie zbliżenie tekstowe można byłoby rozjaśnić próbą nadania utworowi autorytetu za pomocą powiązania go ze znaną opowieścią kanoniczną.

${ }^{123} \mathrm{O}$ wtórności wariantów harmonizowanych zob. E. T o v, The Nature and Background of Harmonizations in Biblical Manuscripts, JSOT 31/1985, s. 3-29; t e n ż e, Textual Criticism of the Hebrew Bible, Minneapolis 2001, s. 307. 


\begin{tabular}{|c|c|}
\hline $\begin{array}{l}\text { ישפנב ינא יתרמא - niebiblijny wyraz, praw- } \\
\text { dopodobny odsyłacz do języka Księgi Ko- } \\
\text { heleta }\end{array}$ & brak \\
\hline & brak \\
\hline 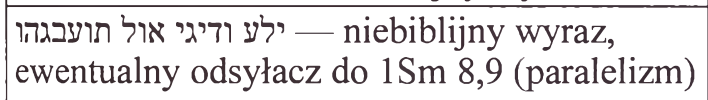 & brak \\
\hline ירבד תא םיצעה & brak \\
\hline $\begin{array}{l}\text { ישעמ תא ואוצהו prawdopodobny odsyłacz } \\
\text { do Ps 148,8--10 (paralelizm między tym } \\
\text { a poprzednimi czterema wierszami) }\end{array}$ & brak \\
\hline 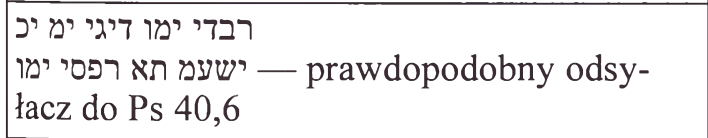 & ינדאל דיגי ימו \\
\hline 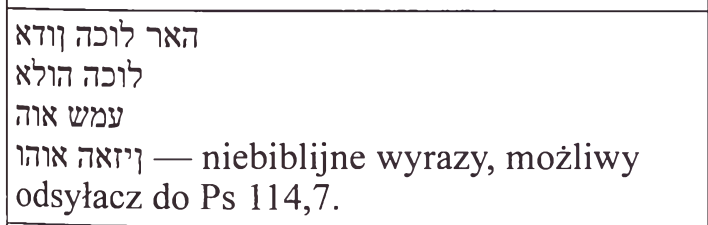 & $\begin{array}{l}\text { הוהי אוה אוה - ewen- } \\
\text { tualny odsyłacz do } \\
\text { 1Krn 16,14 }\end{array}$ \\
\hline ינחשומל ואיבנ חלש & וכאלמ חלש אוה \\
\hline - niebiblijny wyraz - ינלדגל לאומש תא & brak \\
\hline 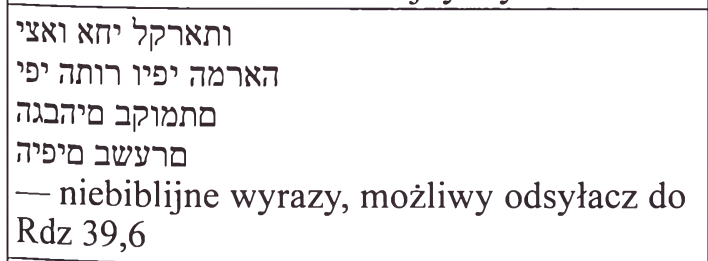 & טילדגו םיפי יחא \\
\hline הוהי רחב איהולא & הוהי םב הצר אולו \\
\hline ואוצה רחאמ ינחקיו חלשיו & ואצה רחאמ ינחקיו \\
\hline שדוקה ןמשב ינחשמיו & ותחשמ ןמשב ינחשמיו \\
\hline 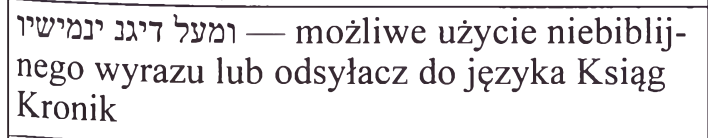 & brak \\
\hline niebiblijny wyraz - ותירב ינבב לשומו & brak \\
\hline
\end{tabular}


Podsumowując wszystkie posiadane przez nas dane, skłaniamy się ku następującej wersji powstania tekstu Psalmu 151. Wydaje się, że ta część tekstu hebrajskiego, która jest zgodna z przekładem Septuaginty, ma w sobie ślady nieco innej autorsko-redaktorskiej strategii niż fragmenty, których brak w tekście greckim, dlatego istnieje wielkie prawdopodobieństwo, że te dwie części psalmu zostały stworzone przez różnych autorów i w innym czasie. Krótsza wersja wydaje się pierwotna, wychodząc od razu z dwóch założeń. Po pierwsze, tekst hebrajski tam, gdzie można porównać go z przypuszczalnym Vorlage Septuaginty, wygląda na tekst harmonizujący, który powstał w wyniku wtórnej korekty redaktorskiej. Po drugie, tylko te fragmenty, których brak w przekładzie greckim, zawierają widoczne ślady późniejszego języka lub niezwykłego użycia słów.

Każdy z tych czynników sam $\mathrm{z}$ siebie nie pozwala na absolutnie pewne stwierdzenie pierwotności jednej z redakcji. Jednak razem świadczą one o tym, że najpierw został utworzony tekst grecki, później zaś do niego został dołączony nowy materiał zawierający pewną liczbę współczesnych redaktorowi idiomatów religijnych (לוכה קודא, ותירב ינב). Przy tym psalm w tych czasach mogło się uważać za kanoniczny (zdaniem J. A. Sandersa, G. H. Wilsona i P. W. Flinta) lub miał ten utwór aspiracje do włączenia do kanonu (por. Septuagintę). Skutkiem tego mogło stać się to, że podczas dodania nowego — „niebiblijnego" - słownictwa jednocześnie miały miejsce dwa podobne zjawiska. Pierwotny tekst krótszej redakcji odpowiadającej Vorlage Septuaginty został leksykalnie zbliżony do prozaicznego opowiadania o Dawidzie, dodatkowe zaś fragmenty zostały utworzone przy użyciu oczywistych odsyłaczy do ksiąg kanonicznych Starego Testamentu, wśrod których głównymi stały się Psałterz i ta część Księgi Rodzaju, ktora opowiada historię Józefa. ${ }^{124}$

Alexander FARUTIN

${ }^{124} \mathrm{~W}$ tym zresztą także nie ma nic dziwnego, ponieważ w pewnym sensie te dwie historię są dość podobne; w obu pojawia się motyw rywalizacji z braćmi i rozpaczliwego stanu jednego z synów. 